Ljubljana

\title{
INFLECTION OF MODERN ICELANDIC VERBS AND PRONOUNS
}

Summary: The present paper is a list of modern Icelandic verbs and pronouns analysed into their respective stems and endings. Under each item it is stated which phonological rules, if any, apply in the derivations of its grammatical forms. The following items of the list should be consulted for new phonological rules: (3), (6), (31), (37), and (49); see also the Appendix. A grammatical innovation has been implemented in the list, namely the so-called REPLACING ENDINGS; see the Introduction. 1

Introduction. The list below contains the analyses of a number of modern Icelandic verbs and pronouns into their respective stems and endings. The list continues Orešník 1976, containing similar analyses of a number of modern Icelandic nouns, adjectives, and adverbs. As stated o. $\underline{\text { c. }}$, there are two main reasons for releasing these two lists: (a) Such analyses have not been published before. (b) As matters stand now, the division of labour between the morphological and phonological components of grammar is to a considerable extent arbitrary; it is therefore necessary to state explicitly what the researcher relegates into the one, and what into the other component. As many examples below illustrate, the number and/or content of morphological and phonological rules depends crucially on this division.

The lexical items treated in the list have been culled from the handbooks, notably from Einarsson 1945.

Many of the phonological rules whose existence is assumed here or elsewhere in the literature on modern Icelandic can be dispensed with if (a) the cut between the stem and the ending is moved one or more segments towards the beginning of the word, and (b) the rule regulating the intra word consonantal sandhi is formulated so that it truncates, one by one, starting from the right, the stem final consonantal segments, until a representation is reached that conforms with the surface phonetic constraints on the consonantal clusters of modern Icelandic.

Point (a) can be illustrated with the example hafs. Tradition recognises the ending - s in the gen. sg. hafs [hafs] of haf [ha:v] "sea", so that the pho-

1 My thanks are due to Miss Margaret G. Davis, who has corected my English, and to Baldur Jónsson, Magnús Pétursson, Stefán Karlsson, and Svavar Sigmundsson, who have patiently answered my questions about modern Icelandic morphology and pronunciation. 
nological representation of the form is /hav+s/ (I disregard the quantity as immaterial here), and a phonological rule (called the Continuant Devoicing Rule in Orešnik 1972) devoices the $/ \mathrm{v} /$ to $/ \mathrm{f} /$ before $/ \mathrm{s} /$. An alternative analysis is to divide the form hafs so that the ending is $-\underline{f s}[\mathrm{fs}]$. The ending $-f \underline{s}$ is to be viewed as that variant of the desinence $-\underline{s}$ used after stem final $/ \mathrm{v} /$. Under this analysis the Continuant Devoicing Rule does not apply in the derivation of hafs, and its underlying representation is $/ \mathrm{hav}+\mathrm{fs} /$.

Point (b) can be illustrated with the imp. sg. griptu [ kriftY] of grípa "grasp". Traditionally the ending of gríptu is -tur, so that the phonological representation of the form is $/ \mathrm{krip}+\mathrm{tY} /$, and a phonological rule, formulated sub (3) below, opens $/ p /$ to $/ f /$ before $/ t /$. An alternative analysis is to divide the form gríptu so that the ending is -ptu [ ftY]. The ending -ptu is to be viewed as that variant of the desinence -tu used after stem final $/ p /$ (roughly speaking). Under this analysis the rule changing $/ p /$ to $/ f /$ before / $t$ / does not apply in the derivation of gríptu. The phonological representation of griptu is then $/ \mathrm{krip}+\mathrm{ftY} /$. To this representation the rule regulating intra word consonant sandhi applies because the representation does not satisfy the surface phonetic constraints on consonant clusters: /pf/ is not a permitted cluster of modern Icelandic. The rule deletes the stem final $/ \mathrm{p} /$. The resulting representation $/ \mathrm{kri}+\mathrm{ftY} /$ meets the surface phonetic constraints on consonant clusters.

The non-traditional analyses just illustrated do not obey the principle that the number of ending allomorphs should be kept to the minimum. As that principle has never been proved valid, its non-observance in an analysis does not speak against that analysis.

The theoretical importance of the non-traditional analyses presented here lies in the fact that whoever tries to account by rules for the alternations here taken care of by the replacing endings has to disprove these non-traditional analyses first.

As can be seen from the examples adduced, the replacing endings help to reduce the number of "meaningless" morphophonemic (phonological) alternations, and correspondingly increase the number of "meaningful" alternations, i.e. such in which the alternation has a grammatical meaning attached to it. For instance, the replacing ending $-\mathrm{fs}$ of hafs is used in the strong genitive singular masculine/neuter. If hafs is analysed as haf-s, the $[\mathrm{v} \sim \mathrm{f}]$ alternation has no grammatical or lexical meaning.

The intra word consonant sandhi rule can be formulated as follows: 
Condition: The consonant cluster which contains the doomed segment does not satisfy the surface phonetic constraints on consonant clusters.

I. e. any stem final consonant is deleted when followed by a consonant, and the consonant cluster which contains the doomed segment does not satisfy the surface phonetic constraints on consonant clusters. - The rule must reapply to its own output if its structural description (including the Condition) is still satisfied.

Any ending $E$ whose addition to a stem $S$ is followed in the derivation by a non-vacuous application of the intra word consonant sandhi rule to $S+E$ is here called a REPLACING ending. (All other desinences are called ADDED endings.) The above description of replacing endings differs from, and supersedes, the description of replacing endings in my earlier work (Orešnik 1973, 1976).

In the list below, the stem final segments which are deleted by the intra word consonant sandhi rule are delimited by ( to the left of the leftmost doomed segment in the representations; e.g. $/ \mathrm{kri}(\mathrm{p}+\mathrm{ftY} /$ gríptu.

Empirical verification of concrete replacing endings is possible in diachronic linguistics. For instance, if a replacing ending, say, one used after n-final stems only, becomes used after vowel final stems as well, that fact can be construed as evidence in favour of the existence of that replacing ending. For some Icelandic examples of this type see Orešnik 1973.

Two arguments can be adduced in favour of the use of the replacing endings:

(1) Those phonological representations of word-forms not utilising replacing endings suffer from an unavoidable arbitrariness which can be described as follows. Given a set $S$ of ending allomorphs which are all mutually in complementary distribution, it is necessary to ascertain a "basic" ending allomorph $B$ and to use $B$ in the phonological representations of all the word-forms which display an ending allomorph of the set $S$ on the systematic-phonetic level. For instance, the so-called dental suffix of modern Icelandic verbs appears in a number of shapes, e.g. $/ \mathrm{d} /, / \mathrm{t} /, / \mathrm{th} /$, etc., cf. the weak preterits heyr $+\mathrm{dI}$, tal $+\mathrm{tI}$, Northern Icelandic kynn $+\mathrm{th}_{\mathrm{I}}$, etc. Barring exceptional cases, the distribution of these allomorphs is complementary, and the need arises to choose the "basic" allomorph so that it can be entered into the phonological representations of the regular weak preterits, whereas the remaining allomorphs are derived from it by aid of 
rules. One feels tempted to posit, say, $/ \underline{\mathrm{tal}}+\mathrm{dI} /$, and derive $/ \mathrm{tal}+\mathrm{tI} /$ by aid of rules. The issue is that the choice of the "basic" allomorph always seems to be arbitrary in the sense that the choice is not guided by compelling arguments. The only arguments that I know of for the choice of a certain ending allomorph as "basic" are, (a) that the allomorph in question is the "elsewhere" allomorph in a set of ending allomorphs, and/or (b) that the allomorph in question is used (also) after vowels. Certainly the "basicness" of a given ending allomorph does not follow from such arguments. The use of the replacing endings avoids this problem, because it does away with the need to establish certain endings as "basic".

(2) The replacing endings avoid a problem of principle that can be illustrated with the example already used hafs [ hafs]. If its phonological representation is /havts/ - as it must be if replacing endings are not allowed - there must be a phonological rule in the grammar which devoices the stem final $/ \mathrm{v} /$ to $/ \mathrm{f} /$ before $/ \mathrm{s} /$. Such a rule was formulated in Orešnik 1972 and called the Continuant Devoicing Rule; the rule devoices $/ v, q, r /$ to $/ f, x, r /$, respectively. Since the devoicing takes place before voiceless segments (only roughly speaking; for instance, not before $/ p, t, k /$ ), the implication is that the rule is phonetically conditioned, in other words that it states an assimilation process. However, the circumstance that the operation of the rule is limited to just three voiced segments (other possible candidates for devoicing are $/ \mathrm{m}, \mathrm{n}, \mathrm{l}, \mathrm{d} / \mathrm{)}$, shows that the rule is not phonetically conditioned after all, at least not in any straightforward way. Yet the formulation of the rule is such as if it were stating an assimilation process. This is a problem, because there seems to be no way in the system of phonological representations not utilising replacing endings in which one could formally differentiate between the rules that describe pure phonetic processes and the rules that state more abstract phonological generalisations. In the system utilising replacing endings this problem is avoided: the Continuant Devoicing Rule is not posited, the phonological representation of hafs is /hav $+\mathrm{fs} /$, and the rule which operates on /hav $+\mathrm{fs} /$, the intra word consonant sandhi rule, is not phonetically conditioned: it does not truncate stem-final consonants until a pronounceable sequence of segments is reached, but until the surface phonetic constraints of modern Icelandic are satisfied. In other words, the truncation obeys a non-phonetic principle. (Incidentally, the surface phonetic constraints of modern Icelandic are not phonetically conditioned, for they disallow even some pronounceable segment sequences: for instance, the [ $\mathrm{mpt}]$ of kembdi, disallowed by the surface phonetic constraints of modern Icelandic, is a pronounceable sequence in many languages.)

Consider also the English plural form wolves of wolf. The representation wolf +\{\} , where $\{S\}$ is the plural morpheme, must undergo a minor phonological rule changing the stem-final /f/ to /v/ (whereupon the appropriate plural allomorph is generated). The problem with this solution is that the 
use of a minor phonological rule in the derivation of wolves implies, wrongly, that the representation wolves is phonologically irregular. In reality it is morphologically (morphophonemically) irregular. This fact, however, cannot be stated in the system of description just used. On the other hand, the use of a replacing ending (/wolf $+\mathrm{vz} /)$ relegates the irregularity to morphology, because the difference between, say, chiefs and wolves is now one of endings: chiefs contains the regular plural ending, wolves an exceptional one.

Note on the organisation of the entries in the list below. In not a few cases it has been necessary to adduce alternative analyses of the same data; such analyses are indicated by small Latin characters, (a), (b), (c), ... Some ending allomorphs display more than one morph; such allomorphs are separated by "and". In some instances I could not decide on just one representation of a desinence morph; the sundry possibilities are separated from each other by "or".

In each entry it is stated which morphological and phonological rules apply in the derivations of its sundry grammatical forms. In a few cases the pertinent rules have so far not been formulated; some are therefore given here for the first time, some are left unstated. The list is an indicator of the work that remains to be done.

The endings of the finite verbal forms. It is stated in each entry to which tense and/or mood the endings that follow such a statement belong; first the endings of the singular are enumerated, then after a semicolon, the endings of the plural. The endings of the imperative are given thus: first the ending of the short imperative singular, then the ending of the long imperative singular; after a semicolon the endings of the imperative plural follow in rare cases.

The endings of the past participle. If the verb in question uses the supine only, the ending of that form is given; otherwise the ending of the strong nominative singular masculine is adduced. The declension of the participles (past and present) has been dealt with in Orešnik 1976 sub nos. (43), (131), (132), (149).

The endings of the following forms will not be indicated below save exceptionally: present subjunctive, imperative plural, present participle, and preterit subjunctive. The middle endings will be adduced with some verbs only.

The second person singular forms have two variants, the short and the long ones. The short variant equals the (present) stem or the stem + per- 
son marker. The long variant is the short variant expanded with the suffixed personal pronoun bú in its reduced form -tu, $-\underline{d u}$, - $-\underline{u u}$. Barring the imperatives only the short form is given in the list below. The form of the long variant is predictable in the following way outside the imperative: if the short second person singular ends in $\underline{t}$ or $\underline{\mathbf{d}}$, add $/ \mathrm{Y} /$; if it ends in $\underline{s}$ or $\underline{n}$, add /tY/; otherwise add /dY/. Examples: lest - lestu, berd berdu, vex - vextu, hrín - hríndu, hangir - hangirdu.

The reader should keep in mind the possibility that some of the forms whose existence is implied by the endings enumerated in the list below are not used, or are not common.

The endings of the pronouns. First the endings of the singular are enumerated, then after a semicolon, the endings of the plural. The order of the cases is, nominative, genitive, dative, accusative.

Unlike in my earlier work, and following Magnús Pétursson (e.g. Pétursson 1974), I here use the symbols $p, t, c, k$ to denote the unaspirated voiceless plosives in phonological and phonetic representations. (The traditional symbols are $\mathrm{b}, \mathrm{d}, \mathrm{g}_{j}^{\circ}, \stackrel{\mathrm{g}}{\mathrm{g}}$.) The aspirated plosives are denoted thus: $\mathrm{p}^{\mathrm{h}}$, th, $\mathrm{c}^{\mathrm{h}}, \mathrm{k}^{\mathrm{h}}$. (The symbol $\mathrm{ch}^{\mathrm{h}}$ is used instead of the traditional $\mathrm{k}_{\mathrm{j}}^{\mathrm{h}}$ )

As to the vowel and consonantal quantity, a Southern and a Northern quantity system must be distinguished. (For detail, see Orešnik and Pétursson 1977 and Pétursson in the present volume.) Southern Icelandic has short and long vowels and $\underline{r}$, Northern Icelandic also other short and long consonants. The geographical boundaries between the two quantity systems have not yet been determined. It will be assumed below that the Southern quantity and the linmaeli region on the one hand, and the Northern quantity and the hardmaeli region on the other, overlap to a great extent.

Quite often the only difference between the analysis of verbal and pronominal forms valid for Northern Icelandic (hardmaeli) and that valid for Southern Icelandic (linmaeli) lies in the length of some consonant in either the stem or the ending. To shorten the exposition, only the Northern variant of the stem or ending in question is given, and the Southern variant can be formed from it by deleting the length sign (:) (except after $\underline{r}$ ). For the rules governing quantity, see Orešnik and Pétursson 1977. This paper ought to be referred to in practically all the entries below; instead it is mentioned here once for all.

Quite a few endings are $i$-initial and the stem final guttural is palatal before them, e.g. tak+I [ $\left.t^{h_{a}: c(h) I}\right]$ of taka "take". In all such cases there is an alternative analysis utilising replacing endings: the ending begins with 
$/ \mathrm{c}^{(\mathrm{h})} /$ and the stem final velar is deleted before it by the intra word consonant sandhi rule, e.g. $\underline{\mathrm{ta}}(\underline{\mathrm{k}}+\mathrm{c}(\mathrm{h})$ I. Such alternative analyses of $\underline{\mathbf{i}}$-initial endings, instead of being repeated time and again in the list of forms below, are mentioned here once for all.

Modern Icelandic inflection makes use not only of suffixes but also of infixes. For instance, the nom. sg. m. saell [ saitl] "happy" can be analysed into the stem sael- and the infix / $t /$. The infix is invariably inserted immediately before the last segment of the stem.

\section{The Strong Verbs}

(1) bída "wait". Four suppletive stems: bíd- in the forms of the present stem, beid- in the singular preterit indicative, bid- in the plural preterit indicative and in the preterit subjunctive, bed- in the past participle. Endings: present indicative $/--,+Y r,+Y r ;+Y m,+I A,+a /$, present subjunctive $/+\mathrm{I},+\mathrm{Ir},+\mathrm{I} ;+\mathrm{Ym},+\mathrm{Id},+\mathrm{I} /$, infinitive $/+\mathrm{a} /$, imperative $/--$ and $+\mathrm{t}: \mathrm{Y}$; $+\mathrm{Id} /$, present participle /tantl/, preterit indicative / -- +st, --; +Ym, $+\mathrm{YA},+\mathrm{Y} /$, preterit subjunctive $/+\mathrm{I},+\mathrm{Ir},+\mathrm{I} ;+\mathrm{Ym},+\mathrm{Yd},+\mathrm{Y}$ and $+\mathrm{I} /$, past participle $/+\mathrm{In} /$. The imperative ending $/+t: \mathrm{Y} /$ is replacing, / $/$ í $(\underline{a}+t: Y /$.

(2) hrína "cry". Three suppletive stems: hrín- in the forms of the present stem, hrein- in the singular preterit indicative, hrin- elsewhere. Endings: present indicative singular $/--,--,--/$, imperative $/--$ and $+\mathrm{tY} /$, the rest as sub (1).

(3) Svikja "betray". Five suppletive stems: svik- in the present indicative singular and in the imperative singular, svikj- elsewhere in the forms of the present stem, sveik- in the preterit indicative singular, svik- in the preterit indicative plural and in the past participle, svik $_{j}$ - in the preterit subjunctive. Endings: present indicative $/--,+Y r,+Y r ;+Y m,+I d,+a /$, infinitive $/+a /$, imperative $/--$ and $+\mathrm{tY}$ or $+x t Y /$, preterit indicative /--, + st or +xst, --; $+\mathrm{Ym},+\mathrm{YA},+\mathrm{Y} /$, past participle $/+\mathrm{In} /$; middle endings: present indicative / + st or +xst, +st or +xst, +st or +xst; +Ymst and $+Y$ stYm, +Ist, +ast/, infinitive /+ast/, preterit indicative /+st or +xst, +st or +Xst, +st or +Xst; +Ymst and +YstYm, +Yst, +Yst/, supine /+Ist/. The desinences / $+x t Y /$ and / $+x s t /$ are replacing: /svílk+xtY/, /svílk+xst/. The /st/-initial desinences and / $+\mathrm{tY} /$ require a phonological rule changing the stem final $\mathrm{k}$ to $/ \mathrm{x} /$. The rule can be formulated as follows:

The $p$-to-f and $k$-to-x Rule

$$
\left[\begin{array}{l}
(\mathrm{h}) \mathrm{P} \\
(\mathrm{h}) \mathrm{K}
\end{array}\right]-\left[\begin{array}{l}
\mathrm{f} \\
\mathrm{x}
\end{array}\right] /\left[\begin{array}{l}
\mathrm{P}=\mathrm{p} \text { or } \mathrm{p}^{\mathrm{h}} \\
\mathrm{K}=\mathrm{k} \text { or } \mathrm{k}^{\mathrm{h}} \text {, } \mathrm{cor} \mathrm{ch} \\
\mathrm{T}=\mathrm{t} \text { or } \mathrm{th}
\end{array}\right.
$$


I. e. any $/(\mathrm{h}) \mathrm{p} /$ or $/(\mathrm{h}) \mathrm{p}^{\mathrm{h}} /$, becomes $/ \mathrm{f} /$, and any $/(\mathrm{h}) \mathrm{c} /, /(\mathrm{h}) \mathrm{c}^{\mathrm{h}} /, /(\mathrm{h}) \mathrm{k} /$ or $/(\mathrm{h}) \mathrm{k}^{\mathrm{h}} /$ becomes $/ \mathrm{x} /$, if it is immediately followed by a $/ \mathrm{t} /, / \mathrm{t}^{\mathrm{h}} /$, or $/ \mathrm{st} /$. - Examples: súptu [suftY], sökkti [söxtI]. The rule seems also to operate, or to have operated, before simple /s/, cf. gen. sg. skifs of skip, but there are exceptions. For instance, there is skips, with a plosive before $/ \mathrm{s} /$, beside skifs. The above formulation of the rule is provisional.

The Palatalisation Rule (Orešnik 1977) applies in the non-contracted cases of the past participle. In the contracted cases of the past participle (svikn-) the H-Insertion Rule, partially formulated sub (11) in Orešnik 1976, produces an $/ \mathrm{h} /$ before $\underline{\mathrm{k}}$, and the aspirated $\underline{\mathrm{k}}$ of the Northern svikn- is deaspirated by the Deaspiration Rule formulated sub (6) below.

The present stem variant svik $_{\mathrm{j}^{-}}$can be dispensed with and replaced by the present stem variant svik- if the a- and $\underline{u}$-initial endings of the present tense are made $\underline{k}_{j}$-initial and replacing; for instance, if the $1 \mathrm{p}$. pl. pres. svíkjum is not analysed as / $\mathbf{s v i k}_{j}{ }^{+} \mathrm{Ym} /$, but as $/ \underline{\text { svíl }}+\mathbf{c}(\mathrm{h}) \mathrm{Ym} /$, and the stem final $\underline{k}$ is deleted by the intra word sandhi rule. Likewise the preterit subjunctive stem svik $_{j}$ - can be replaced by svik- if the u-initial endings of the preterit subjunctive are made $\underline{\mathrm{k}}_{\mathrm{j}}$-initial and replacing, e.g. if the $1 \mathrm{p}$. pl. pret. subj. svikjum is analysed as / $\underline{\mathrm{svi}}(\underline{\mathrm{k}}+\mathrm{c}(\mathrm{h}) \mathrm{Ym} /$ and the stem final $\mathrm{k}$ deleted by the sandhi rule.

(4) hrifa "have effect". Three suppletive stems: hrif́- in the forms of the present stem, hreif- in the singular preterit indicative, hrif- elsewhere. Endings: present indicative $/--,+\mathrm{Yr},+\mathrm{Yr} ;+\mathrm{Ym},+\mathrm{Id},+\mathrm{a} /$, infinitive $/+\mathrm{a} /$, imperative /-- and $+\mathrm{dY} /$, preterit indicative /--, +st or $+\mathrm{fst},--;+\mathrm{Ym}$, $+\mathrm{YA},+\mathrm{Y} /$, past participle /+In/; middle endings: present indicative / +st or $+\mathrm{fst}$, +st or +fst, +st or +fst; +Ymst and $+\mathrm{YstYm}$, +Ist, +ast/, infinitive /+ast/, preterit indicative / +st or +fst, +st or +fst, +st or +fst; +Ymst and + YstYm, +Yst, +Yst/, supine /+Ist/. The /f/-initial desinences are replacing, e.g. $/ \underline{h r e i}(\underline{f}+f s t /$. Before $/ \mathrm{s} /$-initial desinences the Continuant Devoicing Rule (Orešnik 1972) applies. In the contracted cases of the past participle (hrifn-) the underlying $/ \mathrm{v} /$ is changed to $/ \mathrm{p} /$ before $/ \mathrm{n} /$ by a rule formulated sub (3) in Orešnik 1976.

(5) grípa "grip". Three suppletive stems: gríp- in the forms of the present stem, greip- in the singular preterit indicative, grip- elsewhere. Endings: present indicative $/--,+\mathrm{Yr},+\mathrm{Yr} ;+\mathrm{Ym},+\mathrm{Id},+\mathrm{a} /$, infinitive $/+\mathrm{a} /$, imperative /-- and $+\mathrm{tY}$ or $+\mathrm{ftY} /$, preterit indicative $/--$, + st or $+\mathrm{fst},--$; $+\mathrm{Ym},+\mathrm{Yd},+\mathrm{Y} /$, past participle / $+\mathrm{In} /$; middle endings: present indicative $/+$ st or $+\mathbf{f s t}$, +st or +fst, +st or $+\mathbf{f s t}$; +Ymst and +YstYm, +Ist, +ast/, infinitive /+ast/, preterit indicative / + st or $+\mathbf{f s t}$, +st or $+\mathbf{f s t}$, + st or $+\mathrm{fst}$; + Ymst and + YstYm, +Yst, +Yst/, supine /+Ist/. The /f/-initial desinences 
are replacing, e.g. /grí(p+fty/. Before /s/-initial desinences the p-to-f and k-to-x Rule, formulated sub (3) above, applies. In the contracted cases of the past participle (gripn-) the H-Insertion Rule, partially formulated sub (11) in Orešnik 1976, produces an $/ h /$ before pn, and the Northern aspirated $p$ of gripn- is deaspirated by the Deaspiration Rule, formulated sub (6) below.

(6) skjóta "shoot". Six suppletive stems: skyit- in the singular present indicative, skjot- elsewhere in the forms of the present stem, skaut- in the singular preterit indicative, skut- in the plural preterit indicative, skytin the preterit subjunctive, skot- in the past participle. Endings of the active voice as sub (1), except that the ending of the imperative is /-- and +htY or infix $\mathrm{h}+$ suffix $\mathrm{Y} /$; middle endings: present indicative $/+\mathrm{st}$, +st, + st; + Ymst and $+Y$ stYm, +Ist, +ast/, infinitive / +ast/, imperative /+st and $+\mathrm{stY} /$, preterit indicative /+st, +st, +st; +Ymst and +YstYm, +Yst, +Yst/, supine /+Ist/. The desinence /+htY/ is replacing:/skjót $t+h t Y /$. The /st/-initial desinences are either replacing, e.g. /skau $(\mathrm{t}+\mathrm{st} /$, or added; in the latter case there must be a phonological rule in the grammar which can be formulated as follows:

\section{$\underline{\text { T-Deletion Rule }}$}

$$
\begin{aligned}
& {\left[\begin{array}{l}
\text {-syllabic } \\
\text {-consonantal } \\
\text {-anterior } \\
\text {-coronal }
\end{array}\right]-\left[\begin{array}{l}
\text { tanterior } \\
\text { tcoronal } \\
\text {-sonorant }
\end{array}\right]-\text { st }} \\
& 1 \\
& 2 \\
& 3 \Rightarrow \emptyset \emptyset 3
\end{aligned}
$$

I. e. any dental obstruent and any $/ \mathrm{h} /$ optionally preceding it are deleted if immediately followed by /st/. Examples: 2p. sg. pret. ind. middle bast $-\underline{\text { batt }}+$ st of binda, supine middle sótst [soust ] - $\underline{\text { sottt }}+$ st of saekja, [prexst] - $\underline{\text { bregd }}+\underline{\text { st }}$ of bregda.

In the contracted cases of the past participle (skotn-) the H-Insertion Rule, partially formulated sub (11) in Orešnik 1976, produces an $/ \mathrm{h} /$ before $\mathrm{tn}$. - After the infix $/ \mathrm{h} /$ of the imp. skjottu and after the $/ \mathrm{h} /$ produced by the $\mathrm{H}$-Insertion Rule in skotn-, the Northern Icelandic stem final / th/ is deaspirated by a phonological rule that can be formulated as follows:

\section{Deaspiration Rule}

$$
[\text { +aspirated }] \rightarrow[\text {-aspirated }] / \mathrm{h}
$$

I. e. every aspirated plosive is deaspirated if immediately preceded by $/ \mathrm{h} /$.

- This formulation is temporary; it ought to be broadened, for deaspiration 
also takes place in some other environments. For those speakers pronouncing aspirated stops even after /h/ (e.g. ekki "not" [ehchI], see Gudfinnsson 1946:210-11) the rule must have a different structural description: $h \quad C$ (= between $/ \mathrm{h} /$ and consonant); Southern speakers may not need the Deaspiration Rule at all.

(7) kjósa "choose". Six suppletive stems: kýs- in the singular present indicative, kjós- elsewhere in the forms of the present stem, kaus- in the singular preterit indicative, kus- in the plural preterit indicative, kys- in the preterit subjunctive, kos- in the past participle. Endings: present indicative $/--,+t,--;+Y m,+I d,+a /$, infinitive $/+a /$, imperative $/--$ and $+\mathrm{tY} /$, preterit indicative /--, +t, --; $+\mathrm{Ym},+\mathrm{Yd},+\mathrm{Y} /$, past participle / $+\mathrm{In} /$; middle endings: present indicative $/+\mathrm{t},+\mathrm{t},+\mathrm{t}$; $+\mathrm{Ymst}$ and $+\mathrm{YstYm},+\mathrm{Ist}$, $+\mathrm{ast} /$, infinitive / $+\mathrm{ast} /$, preterit indicative / $+\mathrm{t}$, $+\mathrm{t},+\mathrm{t}$; $+\mathrm{Ymst}$ and $+\mathrm{YstYm}$, + Yst, +Yst/, supine / +Ist/.

(8) ljúga "tell a lie". Six suppletive stems: lýg- in the singular present indicative, ljug - / ju:/ elsewhere in the forms of the present stem, laugin the singular preterit indicative, $\underline{\operatorname{lug}-}$ in the plural preterit indicative, $\operatorname{lyg}_{j^{-}} / \mathrm{lij} /$ in the preterit subjunctive, $\log -$ in the past participle. Endings: present indicative /--, $+\mathrm{Yr},+\mathrm{Yr} ;+\mathrm{Ym},+\mathrm{I} \mathrm{d},+\mathrm{a} /$, infinitive $/+\mathrm{a} /$, imperative /-- and $+\mathrm{qdY}$ and $+\mathrm{kdY} /$, preterit indicative /--, +st or +xst, --; +Ym, $+\mathrm{Yd},+\mathrm{Y} /$, past participle $/+\mathrm{In} /$. The imperative ending $/+\mathrm{qdY} /$ is used in Southern Icelandic, $/+\mathrm{kdY} /$ in Northern Icelandic. The desinence $/+x s t /$ is replacing, $/ \mathrm{lau}(\mathrm{g}+\mathrm{xst} /$. Before /s/-initial desinences the Continuant Devoicing Rule (Orešnik 1972) applies.

In the past participle the stem final $/ q /$ is palatalised to $/ \mathrm{j} /$ before $/ \mathrm{I} /$ by the Palatalisation Rule (Orešnik 1977) and the stem vowel /o/ is diphthogised to an $i$-diphthong before $/ j /$. In the contracted cases (logn-) the stem final /q/ is changed to $/ \mathrm{k}$ / before $/ \mathrm{n} /$ by a rule formulated sub (3) in Orešnik 1976. The assumption that the underlying final segment of the past participle stem is /q/ is open to doubt, seeing that /q/is never realised on the systematic phonetic level in the forms of the past participle. An alternative analysis is this. The stem is lo- and the case endings begin with / $j /$ in the non-contracted cases (e.g. nom. sg. m. $/ 10+\mathrm{jIn} / ; / 0 /$ is diphthongised to $/ o i /$ before $/ \mathrm{j} /$ ), and with $/ \mathrm{k} /$ in the contracted cases (e.g. dat. pl. $/ 10+\mathrm{knYm} /$ ). This solution has the advantage of being very near to the phonetic facts.

(9) gjalda "pay". Six suppletive stems: geld- in the singular present indicative, gjald- elsewhere in the forms of the present stem, /kalt/ in the singular preterit indicative, guld- in the plural preterit indicative, gyldin the preterit subjunctive, gold- in the past participle. Endings as sub (1), 
except that the desinence of the imperative is $/+1 \mathrm{t}$ and $+1 \mathrm{ty} /$, and the desinence of the second person singular preterit indicative and of the whole singular preterit indicative middle is $/+1 \mathrm{st} /$. The desinences $/+1 \mathrm{lt}(\mathrm{Y}) /$ and /+lst/ are replacing: /gja $(\underline{l d}+1 \mathrm{lt}(\mathrm{Y}) /, / \mathrm{ka}(\mathrm{l} \mathrm{t}+\mathrm{st} /$. The u-Umlaut Rule, discussed in Orešnik MSa, applies in the 1p. pl. pres. gjöldum etc. The /st/-initial desinences are either replacing or added; in the latter case the T-Deletion Rule, formulated sub (6) above, changes, say, /geld+st/ to /gel +st/.

(10) binda "bind". Three suppletive stems: bind- in the forms of the present stem (except possibly in the imperative singular) and in the preterit subjunctive, batt- in the singular preterit indicative, bund- in the plural preterit indicative and in the past participle. Endings as sub (6), except that the active imperative singular is bitt(u); bittu can be analysed as /bi(nd+htY/in the system of replacing endings. In the contracted cases of the past participle (bundn-) the D-Deletion Rule, formulated sub (133) in Orešnik 1976, deletes the $/ t /$ in the cluster ndn, whereupon the two n's merge into one segment. However, the pronunciation with / $t /$ is also heard.

(11) bresta "burst". Five suppletive stems: brest- in the forms of the present stem, brast- in the singular preterit indicative, brust- in the plural preterit indicative, bryst- in the preterit sunjunctive, brost- in the past participle. Endings of the active voice as sub (1), except that there is no desinence in the second person singular preterit indicative, and the ending of the active imperative singular is $/--$ and $+\mathrm{Y} /$.

(12) sökkva "sink (intrans.)". Five suppletive stems: sekk- in the singular present indicative, sobk- elsewhere in the forms of the present stem and in the singular preterit indicative, sukk- in the plural preterit indicative, sykk $_{j}$ in the preterit subjunctive, sokk- in the past participle. Endings: present indicative /--, $+\mathrm{Yr},+\mathrm{Yr} ;+\mathrm{vYm},+\mathrm{vId},+\mathrm{va} /$, infinitive $/+\mathrm{va} /, \mathrm{im}-$ perative /-- and $+\mathrm{tY}$ or $+\mathrm{xtY} /$, preterit indicative /--, +st or +xst, --; $+\mathrm{Ym},+\mathrm{Yd},+\mathrm{Y} /$, past participle $/+\mathrm{In} /$. The $/ \mathrm{x} /-$ initial desinences are replacing, e.g. /sö $(h k+x t Y /$. Before $/ \mathrm{t} /-$ and /st/-initial desinences the p-to-f and $k-t o-x$ Rule, formulated sub (3) above, applies. In the non-contracted cases of the past participle the stem final $\underline{\mathrm{k}}$ is palatalised by the Palatalisation Rule (Orešnik 1977).

The preterit subjunctive stem $\mathrm{sykk}_{j^{-}}$can be replaced by sykk- if the $\underline{\underline{u}}-$ -initial preterit subjunctive endings are made $\underline{k}_{j}$-initial and replacing, e.g. if the $1 \mathrm{p}$. pl. pret. subj. sykkjum is not analysed as $/ \mathrm{sIhc}+\mathrm{Ym} /$, but as $/ \mathrm{sIhk}+\mathrm{cYm} /$, and the stem final $/ \mathrm{k} /$ is deleted by the intra word consonant sandhi rule. 
(13) hrinda "push". Three suppletive stems: hrind- in the forms of the present stem (with a complication in the active imperative singular) and in the preterit subjunctive, hratt- in the singular preterit indicative, hrundin the plural preterit indicative and in the past participle. Endings as sub (6), except that the imperative singular is hrittu; its ending can also be $/--$ and $+t^{\mathrm{h}} \mathrm{Y}$ and $+\mathrm{ntY}_{\mathrm{t}} /$, where $/ \mathrm{t}^{\mathrm{h}} \mathrm{Y} /$ is used in Northern Icelandic only, and $/+n t Y /$ in Southern Icelandic, and both endings are replacing; e.g.


the system of replacing endings. In the contracted cases of the past participle (hrundn-) the D-Deletion Rule, formulated sub (133) of Orešnik 1976, deletes the /t/ in the cluster ndn, whereupon the two $\underline{n}$ 's merge into one segment. However, the pronunciation with $/ \mathrm{t} /$ is also heard.

(14) stinga "prick, pierce". Four suppletive stems: sting- in the forms of the present stem (optionally in the imperative singular), stakk- in the singular preterit indicative, stung- in the plural preterit indicative and in the past participle, styng $_{j}$ in the preterit subjunctive. Endings: the endings in the forms of the present stem as sub (1), except that the imperative ends in /-- and +tY/, and is also stíkk and stíktu; stíkk can be analysed as /sti(ng+hk/, stíktu as /sti(ng+xtY/, in the system of replacing endings. Preterit indicative / $/-$, st or +xst, --; $+Y \mathrm{~m},+Y \mathrm{~A},+\mathrm{Y} /$, past participle $/+\mathrm{In} /$; middle endings: present indicative / + st, +st, +st; +Ymst or +YstYm, +Ist, +ast/, infinitive / +ast/, the rest of the endings as sub (12). The Palatalisation Rule (Orešnik 1977) applies before $/ \mathrm{I} /$-initial endings. The stem final $\mathrm{g}$ is deleted between $/ \mathrm{h} /$ and $/ \mathrm{t} /$ or $/ \mathrm{s} /$ or $/ \mathrm{n} /$ by a rule discussed in Orešnik 1977, fn. 2; the endings / $/$ tY/ and / + st/ can be replacing: /sting $+\mathrm{tY} /$, /stin$(\mathrm{g}+\mathrm{st} /$.

The preterit subjunctive stem styng $_{j^{-}}$can be replaced by the stem stingif the $\underline{u}$-initial endings of the preterit subjunctive are made $g_{j}$-initial and replacing; e.g. if the $1 \mathrm{p} . \mathrm{pl}$. pret. subj. is not analysed as $/ \mathrm{styng}_{\mathrm{j}}+\mathrm{Ym} /$, but as /sting +cYm/ and the stem final $\mathrm{g}$ is deleted by the intra word consonant sandhi rule.

(15) bregda "move quickly". Four suppletive stems: bregd- in the forms of the present stem, brá- in the singular preterit indicative, bruge- in the plural preterit indicative and in the past participle, brygd- in the preterit subjunctive. Endings: the endings of the active voice as sub (1), except that the imperative ends in /-- and $+\mathrm{Y} /$; middle endings: present indicative / + st or +xst, +st or +Xst, +st or +Xst; +Ymst and +YstYm, +Ist, +ast/, infinitive $/$ ast/, imperative / + st or $+x s t$ and $+s t Y$ or $+x s t Y /$, preterit indicative / $+s t$, +st, +st; +Ymst and +YstYm, +Yst, +Yst/, supine /+Ist/. The /x/-initial endings are replacing: / bre(gd $+x s t /$. The $\mathrm{g}$ of ga is a plosive in the Northern pronunciation; $\underline{a}$ is devoiced after it in word final position (as in bregd) 
if a pause or a voiceless segment follows; the devoicing is performed by the Cluster Devoicing Rule (Orešnik 1972). Béfore the desinence /+st/ of the singular present indicative middle the stem final $\underline{\mathrm{d}}$ is deleted by the T-Deletion Rule, formulated sub (6) above, whereupon the Southern /q/ is devoiced by the Continuant Devoicing Rule (Orešnik 1972), and the Northern $/ \mathrm{k} /$ is opened to $/ \mathrm{x} /$ by the $\mathrm{p}-$ to-f and $\mathrm{k}-$ to- $\mathrm{x}$ Rule, formulated sub (3) above. In the contracted stem of the Southern past participle (brugen-) a rule mentioned in Orešnik 1971:54 fn. 3 elides the $\underline{d}$ between /q/ and $/ \mathrm{n} /$. This rule must follow $/ \mathrm{qn} / \rightarrow / \mathrm{kn} /$ (see Orešnik 1976 sub (3)), otherwise [prYkn-] would result.

(16) Syngja "sing". Four suppletive stems: syng- in the singular present indicative and in the imperative singular, syng $j^{-}$elsewhere in the forms of the present stem and in the preterit subjunctive, song- in the singular preterit indicative, sung- in the plural preterit indicative and in the past participle. The endings as sub (1), except that the imperative ends in $/--$ and $+\mathrm{tY} /$. The stem final $\mathrm{g}$ is deleted between $/ \mathrm{h} / \mathrm{and} / \mathrm{t} / \mathrm{or} / \mathrm{s} /$ or $/ \mathrm{n} /$ by a rule discussed in Orešnik 1977 , fn. 2 ; the $/ \mathrm{t} /-$ and $/ \mathrm{s} /$-initial endings can be replacing, e.g. /syn $(\mathrm{g}+\mathrm{tY} /$. The Palatalisation Rule (Orešnik ibidem) applies in the non-contracted cases of the past participle and palatalises the stem final $\mathrm{g}$, whereupon $/ \mathrm{g} /$ is changed to $/ \tilde{\mathrm{n}} /$ by the Nasal Assimilation Rule, formulated sub (49) below.

The stem variant syng $j^{-}$can be replaced by the stem variant syng- if the a- and u-initial desinences of the present stem forms and of the preterit subjunctive are made $\mathrm{gj}_{\mathrm{j}}$-initial and replacing; e.g. if the lp. pl. pres. syngjum is not analysed as / syng $_{j}+\mathrm{Ym} /$ but as $/ \mathbf{s y n}(\mathrm{g}+\mathrm{cYm} /$, and the stem final $g$ is deleted by the intra word consonant sandhi rule.

(17) bera "carry". Five suppletive stems: ber- in the forms of the present stem, bar- in the singular preterit indicative, bár- in the plural preterit indicative, baer- in the preterit subjunctive, bor- in the past participle. Endings: present indicative $/--,+d,--;+Y m,+I d,+a /$, infinitive $/+a /$, imperative /-- and $+d \mathrm{Y} /$, preterit indicative $/--$, +st or $+\mathrm{rst},--;+\mathrm{Ym}$, $+\mathrm{Yd},+\mathrm{Y} /$, past participle / $+\mathrm{In} /$; middle endings: present indicative / + st or $+\mathrm{rst},+\mathrm{st}$ or $+\mathrm{rsst}$, +st or +rst; +Ymst and +YstYm, +Ist, +ast/, infinitive /+ast/, preterit indicative / + st or + rst, +st or +rst, +st or +rsst; +Ymst and $+Y$ stYm, $+Y$ st, $+Y s t /$, supine $/+\mathrm{Ist} /$. The $/ \mathrm{r} /$-initial endings are replacing, e.g. /be(r+rst/. Before /s/-initial endings the Continuant Devoicing Rule (Orešnik 1972) applies. In the contracted cases of the past participle (born-) a / $t$ / is inserted between $\underline{r}$ and $\underline{n}$ by a rule formulated sub (12) in Orešnik 1976.

(18) koma "come". Three suppletive stems: kem- in the singular present indicative, kom- elsewhere in the forms of the present stem, in the prete- 
rit indicative, and in the past participle, kaem- in the preterit subjunctive. Endings as sub (1), except that the desinence of the imperative singular is $/--$ and $+\mathrm{tY}$ and $+\mathrm{ntY} /$, where $/+\mathrm{ntY} /$ is a replacing ending: $/ \underline{\mathrm{ko}} \underline{\mathrm{m}}+\mathrm{ntY} / \rightarrow$ kontY/. The imp. komdu is pronounced with $\underline{m}$ or with $\underline{n}$. (There is no comparable vacillation in the middle imperative komstu; here $\underline{m}$ is never pronounced as n..) In the system of added endings, the imp. komdu must be an exception, for it is unlikely that there is an optional phonological rule $m \rightarrow n / t$ especially for this form.

(19) gefa "give". Four suppletive stems: gef- in the forms of the present stem and in the past participle, gaf- in the singular preterit indicative, gáfin the plural preterit indicative, gaef- in the preterit subjunctive. Endings as sub (4). In the contracted cases of the past participle (gefn-) underlying $/ \mathrm{v} /$ is changed to $/ \mathrm{p} /$ before $/ \mathrm{n} /$ by a rule formulated sub (3) in Orešnik 1976.

(20) sjá "see". Four suppletive stems: sé- in the singular present indicative and in the past participle, sjá- elsewhere in the forms of the present stem, sá- in the preterit indicative, saej- in the preterit subjunctive. Endings: present indicative $/--,+r d,+r ;+Y m,+I d,--/$, infinitive $/--/$, imperative /-- and $+\mathrm{dY} /$, preterit indicative /--, +st, --; +Ym, +YA, +Y/, past participle $/+\mathrm{dYr} /$; middle endings as sub (1), except that the supine has the desinence / + st $/$.

(21) liggja "lie". Five suppletive stems: ligg- in the singular present indicative and in the imperative singular, $\underline{\operatorname{ligg}_{j}}$ elsewhere in the forms of the present stem, lá- in the preterit indicative, laej- in the preterit subjunctive, leij- in the supine. Endings as sub (1), except that the desinence of the imperative singular is /-- and + $\mathrm{dY}$ or $+q d Y /$ in Southern Icelandic, /-- and + $\mathrm{dY} /$ in Northern Icelandic, and that the desinence of the singular present indicative middle is $/+$ st or $+x s t /$. The desinence $/+q d Y /$ is replacing $/ \underline{\mathrm{i}}(\mathrm{gg}+q \mathrm{dY} /$. The Southern imp. / liggtaY/ is changed to /IIqdY/ by the Southern Opening Rule, formulated sub (31) below. The desinence / $x$ st/ is replacing: / $\underline{\mathrm{li}}(\mathrm{gg}+\mathrm{xst} /$. The $\mathrm{p}-\mathrm{to}-\mathrm{f}$ and $\mathrm{k}-\mathrm{to}-\mathrm{x}$ Rule, formulated sub (3) above, applies before/st/-initial endings.

The present stem variant $\underline{\operatorname{ligg}}_{j^{-}}$can be replaced by ligg- along the lines of (16) above ad finem.

(22) taka "take". Four suppletive stems: tek- in the singular present indicative and in the past participle, tak- elsewhere in the forms of the present stem, tók- in the preterit indicative, taek $_{j-}$ in the preterit subjunctive. Endings as sub (3). The Palatalisation Rüle (Orešnik 1977) applies before $/ \mathrm{I} /$-initial desinences. In the $1 \mathrm{p}$. pl. pres. tökum etc. the u-Umlaut Rule, discussed in Orešnik MSa, applies. In the contracted cases of the 
past participle (tekn-) the H-Insertion Rule, partially formulated sub (11) in Orešnik 1976, produces an $/ \mathrm{h} /$ before $\underline{\mathrm{kn}}$, and the aspirated $\underline{\mathrm{k}}$ of the Northern tekn- is deaspirated by the Deaspiration Rule, formulated sub (6) above.

The preterit subjunctive stem taek tan $_{-}$can be replaced by taek- along the lines of (3) above ad finem.

(23) Sverja "swear". Four suppletive stems: sver- in the forms of the present stem, sor- in the preterit indicative, saer- in the preterit subjunctive, svar- in the past participle. (Here a choice had to be made between the present indicative plural and present subjunctive stems sver-and sverj-. I have arbitrarily opted for sver-, thus for the smaller number of suppletive stems.) Endings as sub (17.), except that the desinences of the plural present indicative are $/+\mathrm{jYm},+\mathrm{jId},+\mathrm{ja} /$, and of the infinitive $/+\mathrm{ja} /$. In the contracted cases of the past participle (svarn-) a / $/$ is inserted between $\underline{r}$ and $\underline{n}$ by the $\mathrm{D}$-Insertion Rule, formulated sub (12) in Orešnik 1976.

(24) bvo "wash". (I) Five suppletive stems: pvae- in the singular present indicative, pvo- elsewhere in the forms of the present stem, pó- in the preterit indicative, pvaej- in the preterit subjunctive, pveig- in the past participle. Endings: present indicative $/--,+\mathrm{rd},+\mathrm{r} ;+\mathrm{Ym},+\mathrm{Id},--/$, infinitive $/--/$, imperative /-- and $+\mathrm{dY} /$, preterit indicative /--, +st, --; +Ym, +Yd, $+\mathrm{Y} /$, past participle / $+\mathrm{In} /$; middle endings as sub. (1). The Palatalisation Rule (Orešnik 1977) applies in the non-contracted cases of the past participle and changes the stem final $/ q /$ to $/ j /$. In the contracted cases of the past participle (bveign-) the underlying / $/$ / is changed to $/ \mathrm{k} /$ before $/ \mathrm{n} / \mathrm{by}$ a rule formulated sub (3) in Orešnik 1976. (That the underlying representation of the past participle stem pveig- ends in $/ \mathrm{q} /$ is open to doubt, seeing that $/ q /$ is never realised phonetically in the forms of the past participle. It may be that the past participle stem is just pvei- and the case endings of the past participle $/ j /-$ and $/ k /$-initial, as suggested sub (8) ad finem above.) (II) Two suppletive stems: pvae- in the singular present indicative and in the preterit subjunctive, pvo- elsewhere. Endings: the forms of the present stem as sub (I); preterit / $\mathrm{dI}$, + $\mathrm{dIr}$, $+\mathrm{dI}$; $+\mathrm{dYm},+\mathrm{dYd},+\mathrm{dY} /$, past participle / $+\mathrm{dYr} /$; middle endings: the forms of the present stem as sub (I); preterit /+dIst, telIst, +dIst; +dYmst and +dYstYm, tdYst, +dYst/, supine /tdst/.

(25) standa "stand". Five suppletive stems: stend- in the singular present indicative, stand- elsewhere in the forms of the present stem except in the imperative singular, stod- in the preterit indicative, staed- in the preterit subjunctive, stad- in the past participle. The imperative singular is statt(u) . Endings: present indicative /--, $+\mathrm{Yr},+\mathrm{Yr} ;+\mathrm{Ym},+\mathrm{Id},+\mathrm{a} /$, infinitive $/+\mathrm{a} /$, preterit indicative /--, +st, --; +Ym, +Yd, +Y/, past participle / +In/; middle endings: present indicative / $/ \mathrm{st}$, $+\mathrm{st}$, $+\mathrm{st}$; +Ymst and $+\mathrm{Y}$ stYm, +Ist, 
+ast/, infinitive /+ast/, imperative stastu, preterit indicative /+st, +st, +st; $+Y m s t$ and $+Y$ stYm, +Yst, +Yst/, supine / + Ist/. The ending $/+s t /$ of the singular present indicative middle is either replacing, / $\underline{\text { sten }}(\underline{d}+\mathrm{st} /$, or added; in the latter case the T-Deletion Rule, formulated sub (6) above, applies. In the 1p. pl. pres. stöndum etc. the u-Umlaut Rule, discussed in Orešnik MSa, applies. The imperative stattu can be analysed as / sta(nd+htY/ in the system of replacing endings. The middle imperative stastu has the desinences $/+$ st / and / + stY $/:$ sta $(\underline{\text { nd }}+$ st $(\mathrm{Y}) /$, with a complication: automatic truncation of $\underline{n}$ would be stopped because stanstu complies with the surface phonetic constraints of modern Icelandic, cf. manstu of muna "remember". In the system of added endings stastu is likewise an exception.

(26) halda "hold". Four suppletive stems: held- in the singular present indicative, hald- elsewhere in the forms of the present stem and in the past participle, /jelt/ in the singular preterit indicative, held- in the plural preterit indicative and in the preterit subjunctive. Endings of the active voice as sub (25), except that the desinence of the imperative singular is a replacing $/+1 \mathrm{t}$ and $+1 \mathrm{t} \mathrm{Y} /$, and the desinence of the second person singular preterit indicative is a replacing $/+1 s t /: / \mathrm{je}\left(\mathrm{l}_{0} \mathrm{t}+1 \mathrm{st} /\right.$. In the system of added endings the imp. halt $(\underline{u})$ is an exception; the second person singular preterit indicative ends in $/+1 s t /$, and certain phonological rules, as yet not formulated, delete the $/ 1 \mathrm{t} /$ / of the stem before this ending. The endings of the middle voice are likewise as sub (25). The middle endings of the singular preterit indicative is a replacing $/+1 \mathrm{st} /: / j \mathrm{e}(\mathrm{l} \mathrm{t}+1 \mathrm{st} /$. The middle imperative singular has the desinences $/+$ st and $/+s t Y /$, which are likewise either replacing or added; in the latter case the $\mathrm{T}$-Deletion Rule applies. In the 1p. pl. pres. höldum etc. the u-Umlaut Rule, discussed in Orešnik MSa, applies.

(27) vaxa "grow". Five suppletive stems: vex- in the singular present indicative, vax- elsewhere in the forms of the present stem and in the past participle, óx- in the singular preterit indicative, ux- in the plural preterit indicative, $\mathrm{yx}-$ in the preterit subjunctive. Endings as sub (7), except that there is no desinence in the second person singular present indicative. In the 1p. pl. pres. vöxum the u-Umlaut Rule, discussed in Orešnik MSa, applies.

(28) höggva "hew". Five suppletive stems: hegg- in the singular present indicative, högg- elsewhere in the forms of the present stem and in the past participle, hjo- in the singular preterit indicative, hjugg- in the plural preterit indicative, hjygg $_{j^{-}}$in the preterit subjunctive. Endings: present indicative /--, $+\mathrm{Yr},+\mathrm{Yr} ;+\mathrm{vYm}$, $+\mathrm{vId}$, +va/, infinitive $/+\mathrm{va} /$, imperative /-and $+\mathrm{dY}$ or $+q \mathrm{dY} /$, preterit indicative /--, +st, --; +Ym, +YA, +Y/, past participle / $+v I n$ and $+\mathrm{In} /$; middle endings as sub (21), except that the de- 
sinences of the plural present are /+vYmst and +vYstYm, +vIst, +vast/, and of the infinitive /+vast/. The Southern Opening Rule, formulated sub (31) below, applies in the Southern Icelandic imp. sg. /högg+eY/. The ending / $+\mathrm{qdY} /$ is replacing, and used in Southern Icelandic only. The Palatalisation Rule (Orešnik 1977) applies in the non-contracted cases of the past participle when the ending is not $/ \mathrm{v} /$-initial. There is a problem with the past participle variant höggvin-. If it is asserted that it becomes höggnwhen contracted, a $\mathrm{v}$-Deletion Rule must be postulated which is otherwise not necessary in modern Icelandic phonology, see Orešnik MSb. I therefore prefer to say, hesitatingly, that höggvin- does not contract; the contracted cases are borrowed from the variant höggin-.

The preterit subjunctive stem hjygg $_{j^{-}}$can be replaced by hjygg- if the $\underline{u}-$ initial endings of the preterit subjunctive are made $g_{j}$-initial and replacing, cf. (16) ad finem above.

(29) hanga "hang". Four suppletive stems: hang- in the forms of the present stem and in the past participle, hékk- in the singular preterit indicative, heng- in the plural preterit indicative, heng $j^{-}$in the preterit subjunctive. Endings: present indicative / $+\mathrm{I},+\mathrm{Ir},+\mathrm{Ir} ;+\overline{\mathrm{Y}} \mathrm{m},+\mathrm{Id},+\mathrm{a} /$, infinitive $/+\mathrm{a} /$, imperative $/--$ and $+\mathrm{tY} /$, preterit indicative $/--$, +st or $+\mathrm{xst},--$; $+\mathrm{Ym},+\mathrm{YA},+\mathrm{Y} /$, past participle $/+\mathrm{In} /$. In the clusters -ngd- and -ngn- the $\mathrm{g}$ is deleted by a rule discussed in Orešnik 1977, fn. 2 . The $/ \mathrm{s} /-$ and $/ \mathrm{t} /-$ -initial endings can also be replacing: han $(\mathrm{g}+\mathrm{tY} /$. Before $/ \mathrm{I} /$-initial desinences the Palatalisation Rule (Orešnik ibidem) changes the stem final $/ \mathrm{k} /$ to $/ \mathrm{c} /$, whereupon $/ \mathrm{\eta} /$ is palatalised to $/ \tilde{n} /$ by the Nasal Assimilation Rule formulated sub (49) below. In the 1p. pl. pres. höngum the u-Umlaut Rule, discussed in Orešnik MSa, applies. The $/ \mathrm{x} /$-initial desinences are replacing, e.g. hé(kk+xst/. Before the /st/-initial endings the T-Deletion Rule, formulated sub (6) above, changes $/ \mathrm{hk} /$ to $/ \mathrm{x} /$.

The preterit subjunctive stem heng $j^{-}$can be replaced with heng- if the $\underline{u}_{-}$ -initial endings of the preterit subjunctive are made $\mathrm{g}_{\mathrm{j}}$-initial and replacing along the lines of (16) ad finem above.

\section{The Weak Verbs}

(30) telja "count". Two suppletive stems: tal- in the preterit indicative and in the past participle, tel- elsewhere. Endings: present indicative /--, $+\mathrm{Yr},+\mathrm{Yr} ;+\mathrm{jYm},+\mathrm{jId},+\mathrm{ja} /$, present subjunctive $/+\mathrm{jI},+\mathrm{jIr},+\mathrm{jI} ;+\mathrm{jYm}$, $+\mathrm{jIe},+\mathrm{jI} /$, infinitive $/+\mathrm{ja} /$, present participle $/+\mathrm{jantI} /$, imperative $/--$ and $+\mathrm{tY} ;+\mathrm{jId} /$, preterit indicative / $+\mathrm{tI},+\mathrm{tIr},+\mathrm{tI} ;+\mathrm{tYm},+\mathrm{tYd},+\mathrm{tY} /$, preterit subjunctive / $+\mathrm{tI}$, $+\mathrm{tIr}$, $+\mathrm{tI}$; $+\mathrm{tYm}$, $+\mathrm{tYA}$, $+\mathrm{tY}$ and $+\mathrm{tI} /$, past participle / $+\mathrm{In} /$; 
middle endings: present indicative / $+\mathrm{st}$, +st, +st; +jYmst and +jYstYm, $+\mathrm{jIst},+\mathrm{jast} /$, present subjunctive / $+\mathrm{jIst}$, +jIst, $+\mathrm{jIst} ;+\mathrm{jYm} \mathrm{Yst}$ and $+\mathrm{jY} \mathrm{YtYm}$, $+\mathrm{jIst},+\mathrm{jIst} /$, infinitive / $+\mathrm{jast} /$, imperative / $+\mathrm{st}$ and $+\mathrm{stY} ;+\mathrm{jIst} /$, preterit indicative / tIst, +tIst, +tIst; +tYmst and +tYstYm, +tYst, +tYst/, preterit subjunctive /ttIst, +tIst, ttIst; +tYstYm, +tYst, +tYst and +tIst/, supine /+Ist/. The u-Umlaut Rule (Orešnik MSa) applies in the plural preterit indicative. The declension of the past participle (talin- $\sim$ tald-) is presented in Orešnik 1976 sub (132).

(31) leggja "lay". (I) Southern inflection. Two suppletive stems: lag- in the preterit indicative and in the past participle, legg- elsewhere. Endings: present indicative /--, $+\mathrm{Yr},+\mathrm{Yr} ;+\mathrm{cYm}$, +IA, +ca/, imperative $/--$ and $+\mathrm{dY}$ or $+\mathrm{qdY} /$, preterit indicative $/+\mathrm{dI} /$, past participle $/+\mathrm{dYr} /$. The $\underline{\mathbf{u}}-$ Umlaut Rule (Orešnik MSa) applies in the plural preterit indicative. The Palatalisation Rule (Orešnik 1977) applies before $/ \mathrm{I} /$-initial endings. The desinence / $+q \mathrm{dY} /$ is replacing: $/ \underline{\mathrm{le}}(\mathrm{gg}+\mathrm{qdY} /$. The /c/-initial desinences are likewise replacing, e.g. $/ \underline{\mathrm{e}}(\mathrm{gg}+\mathrm{cYm} /$. In the supine lagt, from $/ \mathrm{laq}+\mathrm{t} /$, the morphological T-Devoicing Rule, formulated in the Appendix below, devoices the stem final $/ q /$. Alternatively, lagt may contain the replacing ending $/+x t /$ : $/ \mathrm{la}(\mathrm{q}+\mathrm{xt} /$. Exceptionally, this verb has a middle past participle, lagstur, with the added ending / $/$ stYr/ or with the replacing ending / $/$ xstYr/ in the strong nominative singular masculine. In /laq+stYr/ the Continuant Devoicing Rule (Orešnik 1972) devoices the stem final /q/. -ggd- is changed to /qd/ by a phonological rule that can be formulated as follows:

Southern Opening Rule

$$
\mathrm{k} \rightarrow \mathrm{q} / \mathbf{d}
$$

I. e. any $/ \mathrm{k} /$ becomes $/ \mathrm{q} /$ if immediately followed by $/ \mathrm{d} /$. - Examples: imp. leggdu, pret. byggdi of byggja.

(II) Northern inflection. Two suppletive stems: lagg- in the preterit indicative and in the past participle, legg- elsewhere. Endings as sub (I), except that the imp. leggdu cannot end in a replacing / $/ \mathrm{qdY} /$. The supine of active past participle is lagt [-xt], and the middle past participle is lagstur [-xst-]; the underlying representations are / 1 agg $+t /$ and $/ 1$ agg $+s t Y r /$, respectively; the p-to-f and k-to-x Rule, formulated sub (3) above, changes $/ \mathrm{k} /$ to $/ \mathrm{x} /$. Alternatively, these two forms contain replacing endings: $/ \underline{\mathrm{la}}$ (gg $+\mathrm{xt} /$ and / $\mathrm{la}$ (gg+xstYr/.

(32) núa "rub". Two suppletive stems: ný- in the singular present indicative and in the preterit subjunctive, nú- elsewhere. Endings: present indic- 
ative /--, $+\mathrm{rd},+\mathrm{r} ;+\mathrm{Ym},+\mathrm{IA},+\mathrm{a} /$, imperative $/--$ and $+\mathrm{dY} /$, preterit indicative $/+\mathrm{dI} /$, past participle / $\mathrm{In} /$.

(33) flytja "move". Two suppletive stems: flut- in the preterit indicative and in the past participle, flyt- elsewhere. Endings: present indicative as sub (30), imperative /-- and +htY or infix $h+$ suffix $Y /$, preterit indicative / $h$ htI or infix $h+$ suffix I/, past participle / thtYr or infix $h+$ suffix Yr/. The /ht/-initial desinences are replacing, e.g. imp. /fly $(t+h t Y /$. After the infix $/ \mathrm{h} /$ the aspirated plosive of the Northern Icelandic stem is deaspirated by the Deaspiration Rule, formulated sub (6) above.

(34) stydja "support". Two suppletive stems: stud- in the preterit indicative and in the past participle, styd- elsewhere. Endings: present indicative as sub (30), imperative /- and $+\mathrm{t}: \mathrm{Y} /$, preterit indicative $/+t: I /$, past participle / $t \mathrm{t}: \mathrm{Yr} /$. The /t:/-initial desinences are replacing, e.g. imp. / sty( $+\mathrm{t}: \mathrm{Y} /$.

(35) setja "set". Stem set-. Endings as sub (33). Just as exceptionally as leggja, see no. (31) above, setja has a middle past participle, sestur. Its ending is / + stYr/ and it is either replacing, / se $t+s t Y r /$, or added; in the latter case the $T$-Deletion Rule, formulated sub (6) above, applies.

(36) liá "lend". Three suppletive stems: lé- in the preterit and past participle, lja- elsewhere. Endings as sub (32), except that the ending of the past participle is $/ \mathrm{tYr} /$.

(37) hafa "have". (I) Southern inflection. Two suppletive stems: hef- in the singular present indicative and in the preterit subjunctive, haf- elsewhere. Endings: / $/-$ and $+\mathrm{I},+\mathrm{Yr}$ and $+\mathrm{Ir},+\mathrm{Yr}$ and $+\mathrm{Ir} ;+\mathrm{Ym},+\mathrm{Id}$, $+\mathrm{a} /$, imperative / -- and $+\mathrm{AY} /$, preterit indicative / $\mathrm{dII} /$, past participle $/+\mathrm{dYr} /$. The $u$-Umlaut Rule (Orešnik MSa) applies in the first person plural present and in the plural preterit indicative. In the supine haft from /havtt/ the morphological T-Devoicing Rule, formulated in the Appendix below, devoices the stem final $/ \mathrm{v} /$. Haft may alternatively contain the replacing ending / $+\mathrm{ft} /$ : /ha(v+ft/.

(II) Northern inflexion. The same as sub (I), except that a Northern phonological rule changes $/ \mathrm{vd} /$ to $/ \mathrm{pd} /$. The rule can be formulated as follows:

Northern Closing Rule

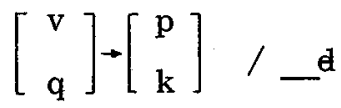

I. e. in Northern Icelandic any $/ v /$ becomes $/ p /$, and any $/ q /$ becomes $/ \mathrm{k} /$, if immediately followed by / $/$. - Example: vígeli of vígja. The rule changes, 
e.g., /havdI/ to /hapdI/. Alternatively, the forms containing /p/ have replacing endings beginning with $/ \mathrm{p} /$, e.g. $/ \mathrm{ha}(\mathrm{v}+\mathrm{pdI} /$.

(38) daema "judge". Stem daem-. Endings: present indicative $/+\mathrm{I},+\mathrm{Ir},+\mathrm{Ir}$; $+\mathrm{Ym},+\mathrm{Id},+\mathrm{a} /$, imperative $/--$ and $+\mathrm{tY} /$, preterit indicative $/+\mathrm{tI} /$, past participle $/+\mathrm{tYr} /$. The Southern Icelandic supine daemt, with voiceless $\underline{m}$ before $\underline{t}$, either contains the replacing ending $/+m t /$, or the ending $/+t /$, and in the latter case the morphological T-Devoicing Rule, formulated in the Appendix below, devoices the stem final $\underline{\mathrm{m}}$.

(39) steikja "roast". Stem steik-. Endings: present indicative $/+\mathrm{I},+\mathrm{Ir}$; $+\mathrm{Ir} ;+\mathrm{c}(\mathrm{h}) \mathrm{Ym},+\mathrm{Il},+\mathrm{c}(\mathrm{h}) \mathrm{a} /$, imperative /-- and $+\mathrm{tY}$ or $+\mathrm{xtY} /$, preterit indicative $/+\mathrm{tI}$ or $+\mathrm{xtI} /$, past participle $/+\mathrm{tYr}$ or $+\mathrm{xtYr} /$. The Palatalisation Rule (Orešnik 1977) applies before /I/-initial desinences. The p-to-f and $k$-to-x Rule, formulated sub (3) above, applies before the $/ t /$-initial desinences. The $/ \mathrm{c}(\mathrm{h}) /-$ and $/ \mathrm{x} /$-initial desinences are replacing, e.g. /stei $(\mathrm{k}$ $+c^{(h)} \mathrm{a} /$, / stei $(\mathrm{k}+x \mathrm{tI} /$. The stem steik- appears as such only in the short imperative singular on the phonetic level, for which reason its status as the basic stem variant can be called into question.

(40) vígja "consecrate". Stem víg-. Endings: present indicative $/+\mathrm{I},+\mathrm{Ir},+\mathrm{Ir}$; $+\mathrm{jYm},+\mathrm{Id},+\mathrm{ja} /$, imperative /-- and $+\mathrm{dY} /$, preterit indicative $/+\mathrm{dI} /$, past participle $/+\mathrm{dYr} /$. The Palatalisation Rule (Orešnik 1977) changes the stem final $/ q /$ to $/ j /$ before $/ \mathrm{I} /$-initial desinences. The $/ \mathrm{j} /$-initial desinences are replacing, e.g. /ví $(\mathrm{g}+\mathrm{jYm} /$. In Northern Icelandic the Northern Closing Rule, formulated sub (37) above, applies in the imp. vigdu, the pret. vígdi, and the past participle vígdur. Alternatively, the Northern Icelandic forms containing $/ \mathrm{k} /$ can have replacing $/ \mathrm{k} /$-initial desinences, e.g. $/ \mathrm{vi}(\mathrm{q}+\mathrm{kdI} /$. The Southern Icelandic supine vígt is underlyingly either $/ \underline{v i}(\mathrm{~g}+x t /$, with a replacing ending, or / víg+t/; in the latter case the morphological T-Devoicing Rule (Appendix below) devoices the stem final /q/.

(41) sökkva "sink (trans.)". Two suppletive stems: sekk- optionally in the preterit subjunctive, sökk- optionally in the preterit subjunctive and obligatorily elsewhere. Endings: present indicative $/+\mathrm{vI}$, $+\mathrm{vIr}$, $+\mathrm{vIr} ;+\mathrm{vYm},+\mathrm{vId}$, $+\mathrm{va} /$, imperative /-- and $+\mathrm{tY}$ or $+\mathrm{xtY} /$, preterit indicative / $+\mathrm{tI}$ or $+\mathrm{xtI} /$, supine $/+\mathrm{t}$ or $+\mathrm{xt} /$. Before $/ \mathrm{t} /$-initial desinences the $\mathrm{p}$-to-f and $\mathrm{k}$-to- $\mathrm{x}$ Rule, formulated sub (3) above, applies. The $/ x /$-initial desinences are replacing, e.g. /sö $(h k+x t Y /$.

(42) byggja "build". Stem bygg-. Endings: present indicative / $+\mathrm{I},+\mathrm{Ir}$, $+\mathrm{Ir} ;+\mathrm{cYm}$, +Id, +ca/, imperative /-- and $+\mathrm{dY}$ or $+\mathrm{qdY} /$, preterit indicative $/+\mathrm{dI}$ or $+\mathrm{qdI} /$, past participle $/+\mathrm{dYr}$ or $+\mathrm{qdYr} /$. The $/ \mathrm{c} /-$ and $/ \mathrm{q} /-$ -initial endings are replacing, e.g. /by $(\mathrm{gg}+\mathrm{cYm} /$, /by(gg+qdI/. /q/-initial desinences are good for Southern Icelandic only. Before $/ \mathrm{d} /$-initial endings 
the Southern Opening Rule, formulated sub (31) above, changes $/ \mathrm{k} /$ to $/ \mathrm{q} /$ in Southern Icelandic. The supine byggt is underlyingly either / $\mathrm{by}(\mathrm{gg}+\mathrm{xt} /$, with a replacing ending, or / $/ \mathrm{bygg}+\mathrm{t} /$; in the latter case the $\mathrm{p}-\mathrm{to}-\mathrm{f}$ and $\mathrm{k}$-to$-x$ Rule, formulated sub (3) above, opens the stem final $\mathrm{gg}$ into $/ \mathrm{x} /$.

(43) lenda "land". (I) Southern inflexion. (a) Two suppletive stems: /ent/ in the active imperative singular, the preterit and the past participle, lendelsewhere. Endings: present indicative as sub (38), imperative /-- and $\overline{+Y} /$, preterit indicative $/+\mathrm{I} /$, supine $/--/$. (b) Stem lend-. Endings: present indicative as sub (38), imperative /-- and $+n_{n} t \mathrm{Y} /$, preterit indicative $/+$ ntI $/$, supine

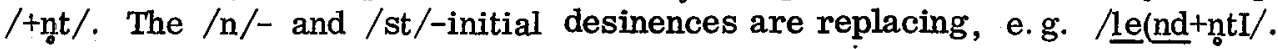
(II) Northern inflexion. Stem lend-. Endings: present indicative as sub (38), imperative /-- and $+t^{\mathrm{h}} \mathrm{Y} /$, preterit indicative $/+\mathrm{t}^{\mathrm{h}} \mathrm{I} /$, supine $/+\mathrm{t}^{\mathrm{h}} /$. The $/ \mathrm{t}^{\mathrm{h}} /-$ -initial endings are replacing: / $\underline{\mathrm{en}}\left(\underline{\mathrm{d}}+\mathrm{t}^{\mathrm{h}} \mathrm{I} /\right.$.

(44) maela "speak". (a) Two suppletive stems: /mail/ in the long active imperative singular, the preterit and the active past participle, mael- elsewhere. Endings as sub (38). (b) Stem mael-. Endings: present indicative as sub (38), imperative /-- +lotY/, preterit indicative $/+1 \mathrm{t} t \mathrm{t} /$, past participle $/+1 \mathrm{tYYr} /$. The $/ 1 /$-initial endings are replacing, e.g. / $/$ ae $(1+1 \mathrm{lt} /$.

(45) meina "mean". (I) Southern inflexion. (a) Two suppletive stems: /mein/ in the preterit and the active past participle, mein- elsewhere. Endings: present indicative $/+a,+a r,+a r ;+Y m,+I d,+a /$, preterit indicative $/+\mathrm{tI} /$, supine $/+\mathrm{t} /$. (b) Stem mein-. Endings: present indicative as sub (a), preterit indicative $/+\mathrm{ntI} /$, supine $/+\mathrm{nt} /$. The $/ \mathrm{n} /$-initial endings are replacing, e.g. /mei(n+ntI/. (II) Northern inflexion. Stem mein-. Endings: present indicative as sub (Ia), preterit indicative $/+\mathrm{t}^{\mathrm{h}} \mathrm{I}$, supine $/+\mathrm{t}^{\mathrm{h}} /$.

(46) kaupa "buy". Two suppletive stems: keyf-/cheif/ in the preterit and past participle, kaup- elsewhere. Endings: present indicative as sub (38), imperative /-- and $+\mathrm{tY}$ or $+\mathrm{ftY} /$, preterit indicative $/+\mathrm{tI} /$, past participle $/+\mathrm{tYr} /$. In the imp. /kaup+tY/ the p-to-f and $\mathrm{k}-\mathrm{to}-\mathrm{x}$ Rule, formulated sub (3) above, applies. The /f/-initial desinence is replacing: /kau $(\mathrm{p}+\mathrm{ftY} /$.

(47) saekja "seek, fetch". Two suppletive stems: sótt- in the preterit indicative and past participle, saek- elsewhere. Endings: present indicative and imperative as sub (39), preterit indicative $/+\mathrm{I} /$, past participle $/+\mathrm{Yr} /$. In the preterit subjunctive the endings are either $/ t /$-initial, in which case the p-to-f and k-to-x Rule, formulated sub (3) above, applies, or /xt/-initial, in which case they are replacing: /sae $(\underline{k}+x t I /$.

(48) bykja "think, seem". Three suppletive stems: paett- in the preterit subjunctive, pott- in the preterit indicative and the past participle, bykelsewhere. Endings: present indicative and imperative as sub (39), preterit $/+\mathrm{I} /$, past participle $/+\mathrm{Yr} /$. 
(49) nefna "name". Stem /nepn/, which becomes /nepn/, with voiceless stem final $\underline{n}$, in the short imp. nefn when the form is followed by a voiceless word-initial segment or by a phonetic pause; the devoicing is performed by the Cluster Devoicing Rule (Orešnik 1972). Endings: (a) present indicative as sub (38), imperative /-- and $+\mathrm{mtY} /$, preterit indicative $/+\mathrm{mtI} /$, supine $/+m t^{h}$ and $+m t /$. The supine desinence $/+m t /$ is used in Southern Icelandic only, $/+\mathrm{mt}^{\mathrm{h}} /$ in Northern Icelandic. The desinence of the middle supine is $/+\mathrm{mst} /$. The $/ \mathrm{m} /-$ and $/ \mathrm{m} /$-initial desinences are replacing: $/ \mathrm{ne}$ (pn $+\mathrm{mtY} /, / \mathrm{ne}(\mathrm{pn}+\mathrm{mtI} /, / \mathrm{ne}(\mathrm{pn}+\mathrm{mst} /$, etc. (b) Present indicative as sub (a), imperative $/--$ and $+\mathrm{tY} /$, preterit indicative $/+\mathrm{tI} /$, supine $/+\mathrm{t} /$ in Southern Icelandic, $/+t^{\mathrm{h}} /$ in Northern Icelandic. Two rules apply before dental-initial endings: first a metathesis rule changes $/ \mathrm{pn} /$ to $/ \mathrm{np} /$, and then an assimilation rule changes $/ \mathrm{n} /$ to $/ \mathrm{m} /$. The metathesis rule can be formulated as follows:

Metathesis Rule

$$
\begin{gathered}
{\left[\begin{array}{c}
\text { - sonorant } \\
\text {-coronal }
\end{array}\right]-\left\{\begin{array}{l}
{[+ \text { lateral }]} \\
{[\text { +nasal }]}
\end{array}\right\}-\left\{\begin{array}{l}
t^{\mathrm{h}} \\
\mathrm{t} \\
\mathrm{st}
\end{array}\right\}} \\
\begin{array}{c}
1 \\
2
\end{array}
\end{gathered}
$$

I. e. in any consonant eluster consisting of $/ \mathrm{p} /$ or $/ \mathrm{v} /$ or $/ \mathrm{k} /$ or $/ \mathrm{q} /$ and a lateral or nasal segment, in that order, the order of the segments is reversed if the cluster is immediately followed by $/ t^{\mathrm{h}} /$ or $/ \mathrm{t} /$ or $/ \mathrm{st} /$. (There is no metathesis before /s/ not followed by $/ \mathrm{t} /:$ gen. $\mathrm{sg}$. tagls of tagl, see Kress 1963:41.) Examples: efla - elfdi, rigna, - ringdi, sigla - past part. middle silgst. The formulation of the rule is provisional. The problem is its optional operation when the second element of the cluster is lateral, cf. efla (pret. efldi and elfdi), sigla (pret. sigldi and sil(g)di), versus its obligatory operation in rigna (pret. ingdi), nefna (pret. nemdi).

Nasal Assimilation Rule

$$
[\text { thasal }]\left[\begin{array}{l}
\alpha \text { anterior } \\
\beta \text { coronal }
\end{array}\right] /-\left[\begin{array}{c}
- \text { sonorant } \\
\alpha \text { anterior } \\
\beta \text { coronal }
\end{array}\right]
$$

I. e. any nasal segment assimilates to the immediately following segment as to the point of articulation. - Examples: $(/ \mathrm{nepn}+\mathrm{tI} / \rightarrow) /$ nenp+tI $\rightarrow$ $/ \mathrm{nemp}+\mathrm{tI} / ;(/ \mathrm{rIkn}+\mathrm{tI} / \rightarrow) / \mathrm{rInk}+\mathrm{tI} / \rightarrow / \mathrm{rInk}+\mathrm{tI} /$. A later rule, which $\mathrm{I}$ am not able to formulate here, deletes the $/ \mathrm{p} /$ of $/ \mathrm{mpt} /$ and $/ \mathrm{mpth} /$. The $/ \mathrm{k} /$ 
of $/ \mathrm{nkt} /$ and $/ \mathrm{hkth}^{\mathrm{h}} /$ is deleted by a rule discussed in Orešnik 1977, fn. 2 . In the Southern Icelandic supine nefnt the morphological T-Devoicing Rule (Appendix below) applies.

(50) sigla "sail, travel". Stem /sIql/. Endings as sub (38), except that the ending of the supine is $/+\mathrm{t}$ and $+\mathrm{th} /$; the latter desinence is probably limited to Northern Icelandic. Before dental-initial desinences the Metathesis Rule, formulated sub (49) above, applies optionally: /sIql $+\mathrm{tI} / \rightarrow / \mathrm{sIlq}+\mathrm{tI} /$. A phonological rule formulated sub (3) in Orešnik 1976 changes /ql/ in final and prevocalic position to $/ \mathrm{kl} /$. In the short imperative the final $/ \mathrm{l} /$ is devoiced (/sIkl/) in certain environments by the Cluster Devoicing Rule (Orešnik 1972). The replacing endings fail with sigla, because they cannot produce the alternation $/ \mathrm{ql} / \sim / \mathrm{q} /$, e.g. in the pret. sigldi. The verbs sigla, efla, etc. can therefore be used as evidence in favour of the existence of the Metathesis Rule.

(51) efla "strengthen". Stem /evl/. Endings as sub (49b). Before dental-initial desinences the Metathesis Rule, formulated sub (49) above, applies optionally: /evl+tI/ $\rightarrow$ /elv+tI/. The morphological T-Devoicing Rule (Appendix below) applies in the supines /evl $+\mathrm{t} /$ and $/ \mathrm{elv}+\mathrm{t} /$. A phonological rule formulated sub (3) of Orešnik 1976 changes $/ \mathrm{vl} /$ to $/ \mathrm{pl} /$ in final and prevocalic positions. The Cluster Devoicing Rule (Orešnik 1972) devoices /pl/ to $/ \mathrm{pl} /$ in the short imp. efl in certain environments. As for the replacing endings, the final remark in (50) applies mutatis mutandis. Einarsson's additional forms $\left[\varepsilon v l t^{h}\right]$ and $[\varepsilon l(v) t h]$, probably Northern, contain the aspirated supine ending $/+\mathrm{t}^{\mathrm{h}} /$, before which the morphological $\mathrm{T}$-Devoicing Rule does not apply. The Continuant Devoicing Rule (Orešnik 1972) does not apply to $/ \mathrm{elv}+\mathrm{th} /$, because its $/ \mathrm{v} /$ is preceded by another consonant.

(52) rigna "rain". Stem rign-; its final $\underline{n}$ is devoiced by the Cluster Devoicing Rule (Orešnik 1972) in the short imp. rign in certain environments. Endings: (a) Present indicative as sub (38), imperative /-- and $+n t Y /$, preterit indicative $/+n t I /$, supine $/+n t^{h}$ and $+\dot{n} t /$. The supine ending $/+n t h /$ is

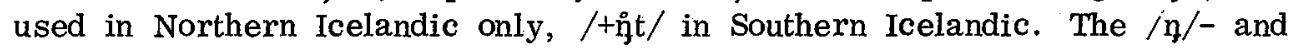
$/ \grave{h} /$-initial desinences are replacing: $/ \mathrm{rI}(\mathrm{kn}+\mathrm{ntY} /, / \mathrm{rI}(\mathrm{kn}+\mathrm{n} \mathrm{tI} /$, etc. (b) Endings as sub (38), except that the supine ends in $/+\mathrm{t}$ and $+\mathrm{t}^{\mathrm{h}} / ; /+\mathrm{t} /$ is used in Southern Icelandic, $/+t^{\mathrm{h}} /$ in Northern Icelandic. Before dental-initial desinences the Metathesis Rule and the Nasal Assimilation Rule, both formulated sub (49) above, apply. Thereafter $/ \mathrm{k} /$ is deleted before dental by a rule discussed in Orešnik 1977, fn. 2. In the Southern Icelandic supine / rIñt/ the morphological T-Devoicing Rule (Appendix below) devoices the $/ \mathrm{h} /$.

(53) lifa "live". Stem lif-. Endings: present indicative as sub (38), imperative /-- and $+d Y /$, preterit indicative $/+d I /$, supine $/+a d /$. 
(54) vaka "be awake". Two suppletive stems: vek- or /vex/ in the preterit subjunctive, vak- elsewhere. Endings of the present indicative as sub (38), imperative $/--$ and $+\mathrm{tY}$ or $+\mathrm{xtY} /$, preterit indicative $/+\mathrm{tI}$ or $+\mathrm{xtI} /$, supine /tad/. The $u$-Umlaut Rule (Orešnik MSa) applies in the first person plural present and in the plural preterit indicative. The Palatalisation Rule (Orešnik 1977) applies before / $/$-initial desinences. The $\mathrm{p}-$ to-f and $\mathrm{k}-\mathrm{to}-\mathrm{x}$ Rule, formulated sub (3) above, applies before $/ t /$-initial desinences. The $/ \mathrm{x} /$-initial desinences are replacing, e.g. $/ \underline{\mathrm{va}}(\underline{\mathrm{k}}+\mathrm{xtI} /$.

(55) segja "say". (I) Southern inflexion. Three suppletive stems: segin the preterit subjunctive, sag- in the preterit indicative and in the past participle, seig- elsewhere. Endings: present indicative $/+\mathrm{I},+\mathrm{Ir},+\mathrm{Ir} ;+\mathrm{jYm}$, $+\mathrm{IA}$, $+\mathrm{ja} /$, imperative $/--$ and $+\mathrm{dY} /$, preterit indicative $/+\mathrm{AI} /$, past participle $/+\mathrm{dYr} /$. The $/ \mathrm{j} /$-initial endings are replacing, e.g. $/ \mathrm{sei}(\mathrm{g}+\mathrm{ja} /$, present part. /sei(g+jantI/. The u-Umlaut Rule (Orešnik MSa) applies in the plural preterit indicative. The Palatalisation Rule (Orešnik 1977) applies before $/ \mathrm{l} /$-initial desinences and changes $/ q /$ to $/ \mathrm{j} /$. (II) Northern inflexion. Three suppletive stems: segg- in the preterit subjunctive, sagg- in the preterit indicative and in the past participle, seig- elsewhere. Endings as sub (I). In the imp. /seigtdY/ the Northern Closing Rule, formulated sub (37) above, applies, or the ending is a replacing $/+\mathrm{kdY} /: / \mathrm{sei}(\mathrm{g}+\mathrm{kdY} /$. In the supines sagt and sagst the endings are / $/ \mathrm{t} /$ and $/+\mathrm{st} /$, before which the $\mathrm{p}-$ -to-f and $k$-to-x Rule, formulated sub (3) above, changes the stem final gg to $/ \mathrm{x} /$. Alternatively, the endings of the supines are replacing, $/+x t /$ and $/+x s t /$.

(56) bora "dare". Two suppletive stems: byr- in the preterit subjunctive, por- elsewhere. Endings as sub (53).

(57) trúa "believe". Two suppletive stems: try- in the preterit subjunctive, trú- elsewhere. Endings as sub (53).

(58) slóra "loaf". Stem slór-. Endings as sub (53), except that the desinence of the supine is / tad and tt or $+r t /$. The morphological T-Devoicing Rule (Appendix below) applies in the supine /slórtt/. The $/ \mathbf{r} /$-initial desinence is replacing: / $\underline{\text { sló }}(\underline{r}+\underline{r} t /$.

(59) loda "stick to". Two suppletive stems: 1yd- in the preterit subjunctive, lod- elsewhere. Endings: present indicative and the supine as sub (53), imperative /-- and $+\mathrm{t}: \mathrm{Y} /$, preterit indicative / $+\mathrm{t}: \mathrm{I} /$. The $/ \mathrm{t}: /-$ initial desinences are replacing, e.g. / $1 \mathrm{o}(\mathrm{d}+\mathrm{t}: \mathrm{I} /$. The stem of the preterit subjunctive can also be lydd-, in which case the desinences of the preterit subjunctive are $/+I /, /+\operatorname{Ir} /$, etc. 
(60) kalla "call". Stem kall-. Endings: present indicative / $+a,+a r,+a r ;$ $+\mathrm{Ym},+\mathrm{Id},+\mathrm{a} /$; imperative $/+\mathrm{a}$ and $+\mathrm{adY} /$, preterit indicative /+adI, +adIr, +adI; +YdYm, +YdYd, +YdY/, past participle /+adYr/. The u-Umlaut Rule (Orešnik MSa) applies in the first person plural present and in the preterit plural, except in the third person plural preterit subjunctive when the desinence is $/+I /$.

byrja "begin". Stem byrj-. Endings as sub (60).

\section{Preterit-Present and Other Irregular Verbs}

(62) vita "know". Three suppletive stems: viss- in the preterit, veit- in the singular present indicative, vit- elsewhere. Endings: present indicative $/--,+$ st, --; +Ym, +Id, +a/, imperative /-- and +htY or infix $h+$ suffix $\mathrm{Y} /$, preterit indicative / $+\mathrm{I} /$, supine $/+\mathrm{ad} /$. The desinence $/+$ st/ is either replacing, / vei $(\underline{t}+s t /$, or added; in the latter case the T-Deletion Rule, formulated sub (6) above, applies. The desinence $/+\mathrm{htY} /$ is replacing, / $\underline{\text { ii }}\left(\mathrm{t}^{+}\right.$ thtY/.

(63) kunna "know (how to)". Three suppletive stems: kynn- in the preterit subjunctive, kann- in the singular present indicative, kunn- elsewhere. Endings: present indicative /--, $+\mathrm{t}^{\mathrm{h}}$ and $+\mathrm{n} t,--;+\mathrm{Ym},+\mathrm{Id},+a /$, preterit indicative $/+I /$, supine $/+a d /$. The desinence $/+n t /$ is used in Southern Icelandic only, $/+\mathrm{t}^{\mathrm{h}} /$ in Northern Icelandic. The desinence $/+\mathrm{nt} / \mathrm{is}$ replacing,

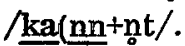

(64) unna "love". Three suppletive stems: ynn- in the preterit subjunctive, ann- in the singular present indicative, unn- elsewhere. Endings: present indicative as sub (63), imperative $/--$ and ${ }^{+} t^{h} \mathrm{Y}$ and + nt $Y /$, preterit indicative $/+\mathrm{I} /$, supine $/+\mathrm{ad}$ and $+\mathrm{t}^{\mathrm{h}}$ and $+\mathrm{t}$ or $+\mathrm{nt} /$. The $/ \mathrm{n} /-$ initial desinences and $/+t /$ are used in Southern Icelandic, the $/$ th $/$-initial desinences in Nor thern Icelandic. The $/ \mathfrak{n} /$-initial desinences are replacing, e.g. $/ \underline{u}(\underline{n} n+$ +ntY/. The morphological T-Devoicing Rule (Appendix below) applies in the supine when its ending is $/+t /$.

(65) burfa "need". Three suppletive stems: pyrf- in the preterit subjunctive, parf- in the singular present indicative, purf- elsewhere. Endings: present indicative /--, $+\mathrm{rft},--;+\mathrm{Ym},+\mathrm{Id},+\mathrm{a} /$, preterit indicative $/+\mathrm{rftI}$ and $+\mathrm{rtI} /$, supine $/+\mathrm{rft}$ and $+\mathrm{rt} /$. The $/ \mathrm{r} /$-initial desinences are replacing, e.g. $/ \mathrm{pu}(\underline{\mathbf{r f}}+\mathbf{r f t I} /, / \mathrm{pu}(\underline{\mathrm{rf}}+\mathrm{rtI} /$. The phonetic forms are [pYrftI], [pYrtI].

(66). muna "remember". Three suppletive stems: $\underline{\text { myn- }}$ in the preterit subjunctive, man- in the singular present indicative, mun- elsewhere. Endings: present indicative $/--,+s t,--;+\mathrm{Ym},+\mathrm{Id},+\mathrm{a} /$, imperative $/--$ and $+\mathrm{tY} /$, preterit indicative $/+\mathrm{tI} /$, supine $/+\mathrm{ad} /$. 
(67) munu "shall, will". Two suppletive stems: myn- optionally in the preterit subjunctive, mun- optionally in the preterit subjunctive and obligatorily elsewhere. Endings: present indicative $/--,+\mathrm{t}^{\mathrm{h}}$ and $+\mathrm{n} t,--;+\mathrm{Ym}$, $+\mathrm{Yd},+\mathrm{Y} /$; imperative, preterit indicative and supine non-existent. The infinitive ends in $/+\mathrm{Y} /$. The ending $/+\mathrm{th} /$ is used in Northern Icelandic only. $/+n t /$ is used in Southern Icelandic and is replacing: $/ \underline{m u}(\underline{n}+\underline{n} t /$.

(68) skulu "shall". Three suppletive stems: skyl- in the preterit subjunctive, skal- in the singular preterit indicative, skul- elsewhere. Endings: present indicative /--, +ltt, --; +Ym, +YA, +Y/; imperative, preterit indicative and supine non-existent. The infinitive ends in $/+Y /$. The desinence $/+\mathrm{l} t /$ is replacing, /ska $(\underline{1+1 \mathrm{l}} /$.

(69) mega "may". Three suppletive stems: mae- or maett- in the preterit subjunctive, má- in the singular present indicative, the preterit indicative, and supine, meig- elsewhere. Endings: present indicative /--, tht, --; $+\mathrm{Ym},+\mathrm{Il}$, $+\mathrm{a} /$, preterit indicative / $\mathrm{htI} /$, supine / $\mathrm{ht} /$. Imperative non-existent. The Palatalisation Rule (Orešnik 1977) applies before /I/-initial desinences and changes the stem final $/ q /$ to $/ j /$.

(70) eiga "own, have". Three suppletive stems: ae- or aett- in the preterit subjunctive, $\underline{a}^{-}$in the singular present indicative, the preterit indicative, and the supine, eig- elsewhere. Endings as sub (69).

(71) vilja "want to". Stem vil-. Endings: present indicative /--, +lit, infix $t ;+j Y m$, $+j I d,+j a /$, preterit indicative $/+t I /$, supine $/+\mathrm{jad} /$. Imperative non-existent. The desinence $/+\mathrm{l} t / \mathrm{is}$ replacing, /vi $(\underline{1}+\mathrm{l} t \mathrm{t} /$.

(72) róa "row". Three suppletive stems: rer- (rér-, rör-) in the preterit, rae- in the singular present indicative, ró- elsewhere. Endings: present indicative / - , $+\mathrm{rd},+\mathrm{r} ;+\mathrm{Ym},+\mathrm{Id},+\mathrm{a} /$, imperative $/--$ and $+\mathrm{dY} /$, preterit indicative $/+\mathrm{I} /$, past participle $/+\mathrm{In} /$.

(73) vera "be". Six suppletive stems: er- in the present indicative, séin the present subjunctive, var- in the singular preterit indicative, vorand vór- in the plural preterit indicative, vaer- in the preterit subjunctive, ver- elsewhere, including in the present optative. (Vera is the only Icelandic verb with a morphological optative.) Endings: present indicative /--, $+\mathrm{rt},--;+\mathrm{Ym},+\mathrm{Yd},+\mathrm{Yl}$, present subjunctive $/--,+\mathrm{rt},--;+\mathrm{Ym},+\mathrm{Yd},+\mathrm{Y}$ and $--/$, present optative $/+\mathrm{I}$, $+\mathrm{Ir}$, $+\mathrm{I} ;+\mathrm{Ym},+\mathrm{Id},+\mathrm{I} /$, imperative $/--$ and $+\mathrm{rtY} /$, preterit indicative /--, +st or $+r s t,--;+\mathrm{Ym},+\mathrm{Yd},+\mathrm{Y} /$, supine $/+\mathrm{Id} /$. Except in the present subjunctive the $/ \mathrm{r} /$-initial desinences are re-

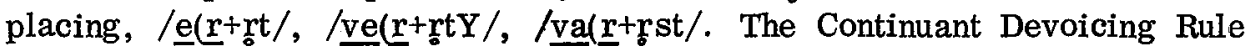
(Orešnik 1972) applies before/s/-initial desinences. 


\section{Inflexion of Pronouns}

In the inflexion of pronouns, as well as sporadically elsewhere, there occasionally occur roots which are never accompanied by an ending, e.g. ég "I". Such roots will be called stems below, but will not be followed by a hyphen as stems elsewhere are. In retrospect I deplore that I did not use the same convention in Orešnik 1976, especially in the chapter on the adverbs.

(74) ég "I". Four suppletive stems: ég in the nominative, mín in the

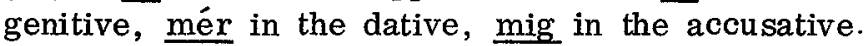

(75) vid "we". Two suppletive stems: okk- outside the nominative, vid in the nominative. Endings $/--,+a r,+\mathrm{Yr},+\mathrm{Yr} /$.

(76) vér "we (honorific)". Three suppletive stems: vér in the nominative, vor in the genitive, oss in the dative and accusative.

(77) hann "he". Two suppletive stems: hon- in the dative, hann- elsewhere. Endings /--, +s, +Ym, --/.

(78) hún "she". Three suppletive stems: henn- in the genitive and dative, han- in the accusative, hun in the nominative. Endings /--, +ar, $+\mathrm{I},+\mathrm{a} /$.

(79) bad "it". Three suppletive stems: pad in the nominative and accusative, bess in the genitive, pví and pí in the dative.

(80) peir $m$. "they". Two suppletive stems: pá in the accusative, peielsewhere. Endings $/+r,+r: a,+m,--/$.

(81) paer f. "they". Two suppletive stems: pei- in the genitive and dative, paer in the nominative and accusative. Endings $/--,+r: a,+m,--/$.

(82) $\operatorname{pau}(\mathrm{g}) \mathrm{n}$. "they". Two suppletive stems: pei- in the genitive and dative, pau and paug in the nominative and accusative. Endings $/--,+r: a$, $+\mathrm{m},--1$.

(83) minn "my, mine". Two suppletive stems: minn- in the nominative/accusative singular masculine, genitive singular feminine, dative singular feminine, nominative/accusative singular neuter, and genitive plural, mínelsewhere. Endings: $\mathrm{m}$. /--, $+\mathrm{s},+\mathrm{Ym},--;+\mathrm{Ir},+\mathrm{a},+\mathrm{Ym},+\mathrm{a} /, \mathrm{f} . /--$, $+a r,+I,+a ;+a r,+a,+Y m,+a r /, n . /+h t,+s,+Y$, tht; --, +a, +Ym, $--/$. The desinence / $/ \mathrm{ht} /$ is replacing, /mi(nn+ht/. 
(84) vor "our(s)". See no. (144) of Orešnik 1976. Emendation: In / vor+t/ the morphological T-Devoicing Rule (Appendix below) applies.

(85) sá "this". For the neuter singular (pad) see no. (79) above. For the plural see nos. (80-82) above. Singular masculine and feminine, six suppletive stems: $\underline{s a}$ in the nominative masculine, pess in the genitive masculine, pei- in the dative masculine, genitive and dative feminine, pann in the accusative masculine, sú in the nominative feminine, pá in the accusative feminine. Endings: $m \cdot \bar{l}--,-,+m,--/$, f. $/--,+r: a r,+r: I,--/$.

(86) pessi "this". Three suppletive stems: penn- in the accusative singular masculine, petta and pettad in the nominative/accusative singular neuter, bess- elsewhere. Endings: $\mathrm{m}$. $/+\mathrm{I}$, +a, $+\mathrm{Ym},+\mathrm{a}$ and $\tan$; $+\mathrm{Ir}$; $\operatorname{tara},+\mathrm{Ym}$, $+a /$, f. $/+\mathrm{I}, \operatorname{tarar},+\operatorname{arI},+\mathrm{a} ; \operatorname{tar}, \operatorname{tara},+\mathrm{Ym},+\operatorname{ar} /, \mathrm{n} . /--,+\mathrm{a},+\mathrm{Y},--$; $+\mathrm{I}$, +ara, $+\mathrm{Ym},+\mathrm{I} /$.

(87) hinn "that, the other" and article. Two suppletive stems: hinn- in the nominative singular masculine, genitive singular feminine, dative singular feminine, and genitive plural, hin- elsewhere. (It cannot be determined which of the two stems is used in the gen. $\mathrm{sg} . \mathrm{m} . / \mathrm{n}$. hins and nom. /acc. sg. n. hitt, hid; I have arbitrarily opted for hin-.) Endings: m. $/--,+s,+Y m,--;+I r,+a,+Y m,+a /$, f. $/--,+a r,+I,+a ;+a r,+a$, $+\mathrm{Ym},+\mathrm{ar} / \mathrm{n}$. / tht and $+\mathrm{d},+\mathrm{s},+\mathrm{Y}$, tht and $+\mathrm{d} ;--,+\mathrm{a},+\mathrm{Ym},--/$. The ending $/ \mathrm{tht} /$, which is replacing $(/ \mathrm{hI}(\mathrm{n}+\mathrm{ht} /)$, is used when the form is a demonstrative pronoun. The ending $/+\mathrm{d} /$, which is likewise replacing $/ / \mathrm{hI}(\mathrm{n}$ $+\mathrm{d} /$ ), is used when the form is an article.

(88) hver "who". Two suppletive stems: hvad in the nominative/accusative singular neuter when the form is used as a noun, hver- elsewhere. Endings: $\mathrm{m} . /--,+\mathrm{s}$ or $+\mathrm{rs},+\mathrm{jYm},+\mathrm{n}$ or $+\mathrm{tn} ;+\mathrm{jIr},+\mathrm{r}: \mathrm{a},+\mathrm{jYm},+\mathrm{ja} /$, f. $/--$, $+r: a r,+r: I,+j a ;+j a r,+r: a,+j Y m,+j a r /, n . /+t$ or $+r i t,+s$ or $+r s,+j Y$, $+\mathrm{t}$ or $+\mathrm{rt}$; -- , $+\mathrm{r}: \mathrm{a},+\mathrm{jYm},--/$. The $/ \mathrm{r} /-$ and $/ \mathrm{r}: /-$ initial desinences are replacing, e.g. /hve $\underline{\underline{r}}+\underline{r} t /$, hve $(\underline{r}+r: a /$. Before / $+s /$ the Continuant Devoicing Rule (Orešnik 1972) applies. Before $/+t /$ the morphological T-Devoicing Rule (Appendix below) applies. In the accusative singular masculine /hver $+n /$ the D-Insertion Rule, formulated sub (12) of Orešnik 1976, applies; the $\underline{r}$ is usually deleted before / $\mathrm{tn} /$. The Cluster Devoicing Rule (Orešnik 1972) devoices the $\underline{n}$ of hvern in certain environments.

(89) einn "one". See no. (138) of Orešnik 1976. The Cluster Devoicing Rule (Orešnik 1972) devoices the final $\underline{\mathrm{n}}$ of einn in certain environments.

(90) nokkur "some". See no. (141) in Orešnik 1976. The morphological T-Devoicing Rule (Appendix below) devoices the $\underline{\mathbf{r}}$ of /nokkur$+t$ /. 
(92) bádir "both". Three suppletive stems: baedi in the nominative/accusative neuter, begg $^{-}$in the genitive, bád- elsewhere. Only the plural exists. Endings: $\mathrm{m} . \mathrm{T}+\mathrm{Ir},+\mathrm{a},+\mathrm{Ym},+\mathrm{a} / \mathrm{f}$. $/+\mathrm{ar},+\mathrm{a},+\mathrm{Ym},+\mathrm{ar} /, \mathrm{n} . /--$, $+\mathbf{a},+\mathrm{Ym},--/$

(93) enginn "nobody". (I) Two suppletive stems: /ehcer / in the nominative/accusative singular neuter, eng- elsewhere. Endings: $\mathrm{m} . /+\mathrm{In},+\mathrm{Is},+\mathrm{Ym}$, tan; +Ir, +ra, $+\mathrm{Ym},+\mathrm{a} /$, f. $/+\mathrm{In},+\mathrm{rar},+\mathrm{rI},+\mathrm{a} ;+\mathrm{ar},+\mathrm{ra},+\mathrm{Ym},+\mathrm{ar} /$, n. $/+\mathrm{t},+\mathrm{Is},+\mathrm{Y},+\mathrm{t} ;+\mathrm{In},+\mathrm{ra},+\mathrm{Ym},+\mathrm{In} /$. The genitive singular masculine/neuter is also einskis and einkis. The Palatalisation Rule (Orešnik 1977) applies before the /I/-initial endings. (II) Three suppletive stems: /ehcer/ in the nominative/accusative singular neuter, eng- in the nominative singular masculine, genitive singular masculine/neuter, nominative singular feminine, and nominative/accusative plural neuter, öng- elsewhere. Endings: m. / $+\mathrm{In},+\mathrm{Is},+\mathrm{Ym}$ and $+\mathrm{VYm}$, +an and +van; +vIr, +ra, +Ym and $+\mathrm{VYm}$, $+\mathrm{va} /$, f. / $+\mathrm{In},+\mathrm{rar},+\mathrm{rI}$, +va; +var, +ra, +Ym and $+\mathrm{vYm},+\operatorname{var} /, \mathrm{n} . /+\mathrm{t}$, $+\mathrm{Is},+\mathrm{Y}$ and $+\mathrm{vY},+\mathrm{t}$; $+\mathrm{In},+\mathrm{ra},+\mathrm{Ym}$ and $+\mathrm{vYm},+\mathrm{In} /$. The genitive singular masculine/neuter is also einskis and einkis. The Palatalisation Rule applies before $/ I /$-initial desinences.

\section{Appendix}

In Orešnik 1972:142 I formulated the following T-Devoicing Rule valid for linmaeli:

$$
[\text {-syllabic }] \rightarrow[- \text { voiced }] / \_^{t}
$$

I. e. in linmaeli any non-syllabic segment is devoiced if immediately followed by $/ t /\left(=/ t^{h} /\right.$ in the system of the present paper $)$. - This rule was supposed to account for consonantal alternations such as shown in the following list:

consonant before the hyphen

\section{voiced}

svalur "cool"

skemma "damage"

vanur "accustomed to" nom. sg. m. sval-ur

inf. skemm-a

nom. sg. m. van-ur voiceless

nom. sg. n. sval-t

supine skemm-t

nom. sg. n. van-t

The formulation of the rule depends crucially upon the assumption that there is a phonetic difference in linmaeli between what is written as $\underline{d}$ and 
what is written as $\underline{t}$ in non-initial position within the word. It has been known for a long time that there is no such difference between $\underline{\mathrm{t}}$ and $\underline{\mathbf{d}}$ word-internally; e.g. the past tenses maeldi "measured" and maelti "spoke" both contain $[\mathrm{t}]$ in linmaeli. For this reason it was tacitly assumed in Orešnik 1972 that the voicelessness of 1 in maelti was not due to the above T-Devoicing Rule. What is not generally recognised is that there is no phonetic difference between $\underline{t}$ and $\underline{d}$ in word-final position either. The only difference between the linmaeli forms nominative singular feminine of the past participles maeld "measured" and maelt "spoken" lies in the $\underline{1}$ (voiced in maeld, voiceless in maelt), so that the word-final sounds of maeld and maelt should both be transcribed as $[t]$, not one with $[t]$ and the other with $\left[t^{\text {h }}\right]$. Consequently the above T-Devoicing Rule cannot distinguish, as it should, between maeld and maelt. (If underlying representations /mael $+\mathrm{t}$ / for maeld, and /mael $+t^{h} /$ for maelt are posited, one of them is a case of absolute neutralisation in the sense of Kiparsky 1968.) I think that cases of devoicing before / $t$ / must be classified into those that take place in the nominative/accusative singular neuter of adjectives (including past participles) and into the remaining cases. While these "remaining" cases must each be treated on an individual basis (examples are pret. maelti and imp. gjaltu), the devoicing in the strong nominative/accusative singular neuter (this includes the supine) is subject to the following morphological rule:

The Morphological T-Devoicing Rule

[-syllabic $][$-voiced $] / t^{t} \#$ in the strong nominative/accusative singular neuter of adjectives

I. e. any non-syllabic segment is devoiced in the strong nominative/accusative singular of adjectives (including past participles) before word final $/ t /$. - This rule correctly devoices the penultimate segments of the forms in the rightmost column of the above list, and of such forms as nom. /acc. sg. n. audugt "rich", ákaft "violent", fagurt "fair".

The morphological T-Devoicing Rule just formulated for linmaeli is valid also for hardmaeli. (This obliterates the need for the special hardmaeli T-Devoicing Rule posited in Orešnik 1972:150). Notice that devoicing does not take place before the aspirated stop $/ \mathrm{t}^{\mathrm{h}} /$, but only before the unaspirated $/ t /$. The hardmaeli forms skemmt, vant, pronounced with voiced nasal, contain the ending $/+t^{\mathrm{h}} /$. One is tempted to assume that the ending is $1+\mathrm{th} /$ in all cases, and that the T-Devoicing Rule, beside executing the devoicing, also deaspirates the $/+\mathrm{th} /$. However, confirmatory evidence is not available. 
The alternations generated by the morphological T-Devoicing Rule can also be expressed by aid of replacing endings (e.g. audugt can be analysed as /audu $(\mathrm{g}+\mathrm{xt} / \mathrm{)}$, so that strictly speaking the existence of the morphological T-Devoicing Rule has not been proved.

Outside the strong nominative/accusative singular neuter of adjectives / $/$ / does not cause devoicing normally, cf. the Vestfirdir forms ger $[t] \underline{\mathbf{i}}$ lag$[t] \underline{i}$, haf $[t] \underline{i}$. In compound words constituent-final / $\mathrm{v} r /$ are not devoiced by the initial $/ \mathrm{p} \mathrm{t} \mathrm{k} /$ of the next constituent, although otherwise constituent-final $/ \mathrm{v} q \mathrm{r} /$ are devoiced before the initial voiceless segments of the next constituent. Examples: haf-gola [-vk-] "sea breeze", sér-deilis [-rt-] "especially", dag-bók [-qp-] "diary"; as against af-komandi [-fkh-] "descendant", for-seti $\left[-\frac{r s-}{a} s-p\right.$ "president", log-fraedingur $[-x f-]$ "lawyer". In view of this the Continuant Devoicing Rule, formulated sub (1) in Orešnik 1972, must be amended so that the devoicing does not take place before $/ \mathrm{p} \mathrm{t} \mathrm{k} /$. Certain statements in Orešnik 1976 have to be amended too. Where the application of T-Devoicing Rule is assumed in Orešnik 1976, replace the relevant statement with the following: the morphological T-Devoicing Rule (as stated above) applies. This emendation has to be undertaken under (127) seint, (137) vont, and (154) langt. Hardmaeli has /tth/ in these forms and consequently no devoicing. Even in hardmaeli the morphological T-Devoicing Rule applies in (121) gult, (128) gamalt, (133) allt; but pronunciations with final $\left[\mathrm{th}^{\mathrm{h}}\right]$ and no devoicing of $\underline{1}$ seem also to be possible, at least sporadically.

\section{REFERENCES}

Einarsson, Stefán: Icelandic. Grammar. Texts. Glossary. Baltimore, 1945. - I have used the corrected fifth printing of 1967.

Guefinnsson, Björn: Mállýzkur. Vol. I. Reykjavík, 1946.

---: Um íslenzkan framburd. Mállýzkur II. Edited and prepared for the press by Olafur M. Ólafsson and Óskar O. Halldórsson. Studia islandica, vol. 23. Reykjavik, 1964.

Kiparsky, Paul: "How abstract is phonology?" Mimeographed, 1968. Printed in a slightly revised form in Three Dimensions of Linguistic Theory, ed. O. Fujimura, 1973.

Kress, Bruno: Laut- und Formenlehre des Isländischen. Halle/Saale, 1963.

Orešnik, Janez: "On the phonological boundary between constituents of Modern Icelandic compound words." Linguistica 11:51-59. Ljubljana, 1971. 
---: "Four Modern Icelandic devoicing rules." Linguistica 12:137-56. Ljubljana, 1972 .

---: "Old Icelandic Consonant Lengthening Rule and Modern Icelandic infixation of /d/." Linguistica 13:229-61. Ljubljana, 1973.

---: "Inflexion of modern Icelandic nouns, adjectives and adverbs." Linguistica 16:97-118. Ljubljana, 1976.

--: "On the modern Icelandic Palatalisation Rule." Dialectology and Sociolinguistics. Essays in honor of Karl-Hampus Dahlstedt. Ed. by Claes-Christian Elert el al. Acta universitatis Umensis. UmeQ Studies in the Humanities, vol. 12. Pp. 137-45. UmeQ, 1977.

---: "Modern Icelandic u-Umlaut from the descriptive point of view." Forthcoming. - Referred to as Orešnik MSa.

---: "The modern Icelandic Epenthesis Rule revisited." Forthcoming. Referred to as Orešnik MSb.

Orešnik, Janez and Magnús Pétursson: "Quantity in modern Icelandic." Arkiv för nordisk filologi $92: 155-71$. Lund, 1977.

Pétursson, Magnús: Les articulations de 1'islandais à la lumière de la radiocinématographie. Collection linguistique publiée par la Société de Linguistique de Paris, vol. LXVIII. Paris, 1974.

---: Drög ad almennri og íslenskri hljódfraedi. Reykjavík, 1976.

Povzetek

\section{FLEKSIJA NOVOISLANDSKIH GLAGOLOV IN ZAIMKOV}

Članek je seznam novoislandskih glagolov in zaimkov, razčlenjenih na osnove in končnice. Pri vsaki besedi je navedeno, katera fonološka pravila delujejo $\mathrm{v}$ izpeljavi njenih oblik. Nova pravila so obravnavana pri naslednjih besedah: (3), (6), (31), (37), (49); glej tudi Dodatek. V seznamu je avtor uporabil neko teoretično inovacijo, t.i. nadomeščujoče končnice; o njih v uvodu članka. 